\title{
Wyłączenie odpowiedzialności ubezpieczyciela w ubezpieczeniach grupowych za śmierć będącą następstwem tzw. choroby istniejącej przed objęciem ubezpieczonego ochroną ubezpieczeniowa
}

Duża popularnościq ciesza się na rynku, szczególnie w kanale bancasurrance oraz w ramach programów pracowniczych, grupowe ubezpieczenia na życie przewidujace postanowienia, w świetle których ubezpieczyciel nie odpowiada za wypadek ubezpieczeniowy będqcy następstwem choroby istniejqcej (lub też zdiagnozowanej czy leczonej) u ubezpieczonego przed przystapieniem do ubezpieczenia. W modelu tym ubezpieczyciele nie żqdajq informacji o stanie zdrowia ubezpieczonych, jednocześnie zastrzegajac możliwość oceny tego stanu już po zajściu wypadku ubezpieczeniowego. Popularności tej wydaje się w ogóle nie przeszkadzać fakt, iż tożsame klauzule zostały uznane przez za abuzywne i wpisane do Rejestru Klauzul Niedozwolonych, a w wielu innych przypadkach, w toku kontroli incydentalnej sqdy odmawiaja im skuteczności. Publikacja niniejsza poświęcona jest z jednej strony dopuszczalności stosowania tego rodzaju wyłączeń odpowiedzialności ubezpieczycieli, a z drugiej strony (nie) prawidłowości dokonywanej dotychczas przez judykaturę ich kwalifikacji prawnej i wyprowadzanych z niej skutków. Uwaga poświęcona zostanie również relacjom między argumentami z »grupowości« ubezpieczeń (ich szczególnego charakteru) a rozwiqzaniami normatywnymi przewidzianymi przez ustawodawcę dla ubezpieczeń na życie w ogólności.

\section{Wstęp}

Postanowienia umów ubezpieczenia osobowego, zwłaszcza zaś umów grupowych ubezpieczeń na życie często zmierzają do wyłączenia odpowiedzialności ubezpieczycieli za wypadki ubezpieczeniowe będące następstwem tzw. chorób istniejących, czyli stanów zdiagnozowanych lub występujacych już przed objęciem ubezpieczonego ochroną ubezpieczeniową, niekiedy nawet 
powstałych w krótkim (kilkudziesięciodniowym) okresie po rozpoczęciu ochrony. Praktyka taka zmierza w oczywisty sposób do minimalizacji zakresu ryzyka, jakie przejmuje ubezpieczyciel w zamian za relatywnie niską składkę ubezpieczeniową. Co więcej, jest to praktyka nadal aktualna mimo dokonania już w roku 2011 i 2012 prawomocnych wpisów w Rejestrze Klauzul Niedozwolonych trzech postanowień w takim właśnie zakresie ograniczających odpowiedzialność ubezpieczyciela ${ }^{1}$.

Ten rodzaj wyłaczenia odpowiedzialności w umowach ubezpieczenia osobowego odpowiada klauzuli pre-existing medical conditions popularnej szczególnie w Stanach Zjednoczonych Ameryki w ramach ogólnych warunków umów ubezpieczeń zdrowotnych zawieranych przed rokiem $2014^{2}$. $Z$ racji swojej atrakcyjności zaczął być on szeroko stosowany również w Europie, wzbudzając tym samym szerokie zainteresowanie organów powołanych do nadzoru nad rynkiem ubezpieczeniowym czy też reprezentujących interesy konsumentów usług finansowych ${ }^{3}$. Wykorzystywany w Polsce szczególnie w umowach zawieranych w sektorze bancassurance oraz w ramach tzw. pracowniczych grupowych ubezpieczeń na życie, zaczął budzić kontrowersje w związku z rosnącą ilością skarg konsumentów kierowanych do Rzecznika Ubezpieczonych (obecnie: Rzecznika Finansowego) ${ }^{4}$.

Problematyka dopuszczalności wyłączenia odpowiedzialności ubezpieczyciela za następstwa chorób istniejących została zasygnalizowana w doktrynie ${ }^{5}$, jednak mimo rosnącej ilości postępowań sądowych, daleko rozstrzygnięciom w tym zakresie do jednolitości, a nawet jeśli zaczyna dominować pogląd o abuzywności postanowień OWU o tożsamych skutkach, to pojawia się pytanie o prawidłowość tak dokonanej kwalifikacji prawnej.

Poruszona problematyka jest o tyle złożona, o ile dotyka specyfiki nienormatywnego ${ }^{6}$ typu umów ubezpieczenia grupowego, na dodatek ubezpieczenia na życie, znajdującego szczególne zainteresowanie ustawodawcy w ramach przepisów kodeksu cywilnego, a także zagadnień związanych z relacjami pomiędzy przewidzianymi przez ustawodawcę sankcjami (bezwzględnej nieważności a bezskuteczności] i zasadami pierwszeństwa ich stosowania. Celem niniejszego opracowania jest nie tylko normatywna i doktrynalna analiza problemu, ale również krytyka praktyki orzeczniczej preferującej model odmowy zastosowania przedmiotowych postanowień OWU w oparciu o zarzut

1. Zob. wpisy nr 3185, 3456 oraz 6044 oraz orzeczenia będące ich podstawą: wyrok Sądu Apelacyjnego w Warszawie z dnia 29 grudnia 2011 r., VI Ca 855/11; wyrok Sąu Apelacyjnego w Warszawie z dnia 17 listopada 2011r., ACa 1472/11; wyrok Sądu Apelacyjnego w Warszawie z dnia 12 czerwca 2012 roku, XVII AmC 1039/09.

2. Zob. m.in. L. Jacobson, Pregnancy a , pre-existing condition'? Yes, for some, PolitiFact.com. Retrieved January 17, 2010; http://www.politifact.com/truth-o-meter/article/2009/aug/18/pregnancy-pre-existing-condition/ [dostęp: 12.12.2017].

3. Zob. m.in. Financial Ombudsman (United Kingdom), Pre-existing medical conditions in short-term insurance policies, http://www.financial-ombudsman.org.uk/publications/technical_notes/medical-conditions.htm [dostęp: 12.12.2017].

4. Zob. Podstawowe problemy bancassurance w Polsce - raport Rzecznika Ubezpieczonych, Rzecznik Ubezpieczonych, Warszawa 2007; https://rf.gov.pl/files/108_40_Raport_bancassurance.pdf [dostęp: 13.12.2017] oraz Aneks do raportu Rzecznika Ubezpieczonych z 2007 r. pt. „Podstawowe problemy bancassurance w Polsce” - skargi z zakresu bancassurance wniesione w 2012 r., Rzecznik Ubezpieczonych, Warszawa 2012; https:// rf.gov.pl/pdf/Aneks_do_raportu_o_bancassurance_2012.pdf [dostęp: 12.12.2017]

5. Por. M. Krajewski, Art. 834, w: Umowa ubezpieczenia. Art. 805-834 KC. Komentarz, Warszawa 2016; W. Kamieński, Wyłaczenie odpowiedzialności ubezpieczyciela z uwagi na przyczyny wypadku dotyczqce okresu przed rozpoczęciem ochrony ubezpieczeniowej, „Rozprawy Ubezpieczeniowe”, nr 19 (2/2015), s. 20-35.

6. Funkcjonującej w praktyce, w oparciu o konstrukcję umowy na cudzy rachunek wyrażoną w art. 808 k.c., nie znajdującej jednak explicite wyrażonej definicji. 
ich abuzywności. Tymczasem wydaje się, że bezwzględnie obowiązujące przepisy art. 834 w zw. z art. 815 k.c. nakazuja - w przypadku umów ubezpieczenia na życie - zakwalifikować takie postanowienia jako nieważne, bowiem sprzeczne z ustawą (art. 58 ust. 1 k.c.).

\section{Specyfika ubezpieczeń grupowych}

Umowa ubezpieczenia grupowego jest występującym w praktyce rodzajem umowy ubezpieczenia na cudzy rachunek?, zawieranej w oparciu o zasadę swobody umów (art. $353^{1}$ k.c.), której normatywnych podstaw należy poszukiwać w art. 808 k.c. Przepis ten wobec regulacji ogólnej, zawartej w art. 805 k.c., stanowi wyjątek dla tożsamości podmiotowej ubezpieczającego i ubezpieczonego - przewiduje bowiem sytuację, w której ubezpieczający zawiera umowę ubezpieczenia dla zabezpieczenia interesu majątkowego innej osoby - ubezpieczonego. Ten ostatni zaś nie jest strona samej umowy ubezpieczenia, aczkolwiek pozostaje podmiotem szerzej rozumianego stosunku prawnego ubezpieczenia. ${ }^{8}$ Tak więc, na skutek zawarcia umowy ubezpieczenia na rzecz osoby trzeciej powstaje trójstronny stosunek zobowiązaniowy, z tym zastrzeżeniem, że ewentualne roszczenia ubezpieczonego mają charakter pierwotny (znajdujac swoje źródło w samej treści umowy ubezpieczenia). ${ }^{9}$ Nie tylko więc to na rzecz ubezpieczonego (osoby trzeciej) w razie zajścia wypadku ubezpieczeniowego wypłacane jest należne odszkodowanie, ale także na jego rzecz w trakcie trwania umowy świadczona jest ochrona ubezpieczeniowa. Występujące w praktyce ubezpieczenia grupowe to głównie, będące przedmiotem niniejszej analizy, ubezpieczenia osobowe, w tym też ubezpieczenia na życie, jednakże brak jest normatywnych przeszkód dla obejmowania w ramach ubezpieczeń grupowych ryzyk majatkowych ${ }^{10}$.

Umowa ubezpieczenia na cudzy rachunek może przewidywać objęcie ochrona jednego tylko ubezpieczonego, ale w praktyce najchętniej konstrukcja ta wykorzystywana jest właśnie do objęcia

7. Tak: J. Pokrzywniak, Art. 808 k.c. w: Kodeks cywilny. Tom II. Komentarz. Art. 450-1088, pod red. M. Gutowskiego, wyd. 1, Warszawa 2016, Nb 8; inaczej: M. Kondek, Art. 808 k.c. w: Kodeks cywilny. Komentarz, pod red. K. Osajdy, wyd. 17, Warszawa 2017, Nb 8; który wskazuje, że „mogą istnieć ubezpieczenia grupowe niebędące ubezpieczeniami na cudzy rachunek". W ostatnim czasie w doktrynie i orzecznictwie pojawia się tzw. koncepcja rozproszonego stosunku ubezpieczenia, zakładająca istnienie ubezpieczeń grupowych, do których nie znajdzie zastosowania art. 808 k.c. Taki rozproszony stosunek ubezpieczenia opierać miałby się na umowie ramowej łączącej ubezpieczyciela i organizatora grupy, która określać miałaby jedynie wysokość składki ubezpieczeniowej i techniczne aspekty zawierania właściwych umów ubezpieczenia. Umowa ramowa nie obejmowałaby eseentialia negotii umowy ubezpieczenia, a nawiązanie stosunku ubezpieczenia sensu stricto następować miałoby dopiero w drodze przyjęcia przez ubezpieczyciela deklaracji przystapienia złożonej przez konkretnego ubezpieczonego, którą poczytywać należałoby za wniosek ubezpieczeniowy (tak: M. Fras, 0 dwóch typach umowy ubezpieczenia grupowego, „Prawo Asekuracyjne” 3/2016, s. 18-34; szerzej: M. Fras Umowa ubezpieczenia grupowego. Aspekty prawne, Warszawa 2015; podobnie: wyrok SN z dnia 12 stycznia 2018 r., II CSK 222/17) ]. De lege lata rozważania zawarte w niniejszym artykule znajdą zastosowanie do wszystkich umów ubezpieczenia grupowego, niezależnie od przyjętej koncepcji czy wybranego rodzaju umowy ubezpieczenia grupowego.

8. W. Mogilski, Umowa ubezpieczenia na rzecz osoby trzeciej, w: Ubezpieczenia w gospodarce rynkowej, t. I, pod red. A. Wasiewicza, Bydgoszcz 1994, s. 83.

9. K. Malinowska, Art. 808, w: Komentarz do niektórych przepisów ustawy - Kodeks cywilny, w: Prawo ubezpieczeń gospodarczych. Tom II. Komentarz, wyd. II. Warszawa 2010, LEX/el.

10. M. Fras, Umowa ubezpieczenia grupowego. Aspekty prawne, Warszawa 2015, s. 74-76. 
nią całej grupy osób trzecich - zazwyczaj pracowników czy klientów instytucji kredytowych. Prawodawca, mając świadomość szerokiego ich występowania w obrocie gospodarczym, posługuje się tym terminem wprost w ustawie o działalności ubezpieczeniowej i reasekuracyjnej ${ }^{11}$, chociaż w żadnym miejscu tej ustawy nie definiuje go (zob. m.in. art. 16 pkt. 10, art. 17 ust. 2, art. 18, 19 u.d.u.r.). Wobec braku definicji ustawowej, doktryna wypracowała własną definicję ubezpieczenia grupowego, w świetle której pod pojęciem tym należy rozumieć „umowy zawierane przez jeden podmiot z ubezpieczycielem lub grupą ubezpieczycieli w celu objęcia ochrona przed określonymi ryzykami zbiorowości osób fizycznych lub prawnych"12. Twórcy unijnego, jednolitego prawa o umowie ubezpieczenia - tj. instrumentu opcjonalnego znanego szerzej pod nazwą $P \varepsilon I C L^{13}$, definiuja umowę ubezpieczenia grupowego, jako „umowę ubezpieczenia zawartą pomiędzy ubezpieczycielem a organizatorem grupy ${ }^{14}$ na rzecz członków grupy pozostających we wspólnym związku z organizatorem grupy" 15 .

Powszechnie przeprowadza się w doktrynie podział ze względu na liczbę objętych ochrona ubezpieczeniowa podmiotów, a więc na ubezpieczenia indywidualne i ubezpieczenia zbiorowe ${ }^{16}$. Odmienności obu tych nienormatywnych typów umów wyrażają się m.in. w sposobie ich zawierania, administrowania ubezpieczeniami i dokonywania oceny i selekcji ryzyka oraz - co dla niniejszego opracowania najistotniejsze - zakresu ochrony ubezpieczeniowej. Wynikaja one z faktu, że w umowie ubezpieczenia grupowego dochodzi do dywersyfikacji ryzyka w ramach pewnej wieloosobowej grupy osób ubezpieczonych. Odnosząc się do nomenklatury i podziałów dokonywanych w starszym piśmiennictwie ${ }^{17}$ w ramach umów ubezpieczenia zbiorowego, przedmiotem dalszych rozważań będą tylko ubezpieczenia grupowe sensu stricto, a więc takie, w których poszczególni

11. Ustawa z dnia 11 września 2015 r. o działalności ubezpieczeniowej i reasekuracyjnej (t.j. Dz. U. z 2017 r. poz. 1170 z późn. zm.; dalej jako „u.d.u.r.”).

12. M. Fras, op. cit., s. 61.

13. Zasady Europejskiego Kontraktowego Prawa Ubezpieczeniowego, ang. Principles of European Insurance Contract Law - dalej jako: „PEICL”. Jest to dokument opracowany w ramach Sieci Europejskiego Prawa Prywatnego, mający na celu zapewnienie w skali europejskiej jednolitości regulacji w zakresie umowy ubezpieczenia - przede wszystkim zaś zagwarantowanie porównywalnego poziomu ochrony ubezpieczającemu, ubezpieczonemu lub innym uprawnionym z umowy ubezpieczenia. Postuluje się sięganie do modelu wyznaczonego w $P E I C L$ w toku prac legislacyjnych nad rozwiązaniami rodzimymi. Z uwagi na przystępność wypracowanego w ramach tego instrumentu modelu wobec praktyki rynkowej, a także aktualność i uniwersalność przyjętych założeń, również w świetle dorobku doktrynalnego i orzeczniczego w Polsce, w niniejszym opracowaniu posłuży przedstawieniu wieloaspektowości problemów nie znajdujących explicite regulacji w prawie polskim. Pełen tekst $P \varepsilon I C L$ w tłumaczeniu na język polski D. Fuchsa, Ł. Szymańskiego i M. Boguskiej na: http://www. restatement.info/ [dostęp: 15.12.2017] (zakładka: PEICL in full text).

14. Należy zauważyć przy tym, że $P E I C L$ posługuje się pojęciem „organizatora grupy” tam, gdzie de lege lata polska doktryna usytuowałaby „ubezpieczającego”. Problem, czy podmioty te można i powinno się utożsamiać zdecydowanie przekracza ramy niniejszego opracowania. Chociaż więc wymaga zasygnalizowania, nie będzie też rozstrzygający dla dalszych rozważań w przyjętym zakresie.

15. Art. 1:201 (?) PEICL.

16. J. Handschke, B. Kęszycka, E. Kowalewski, Problematyka grupowych ubezpieczeń na życie w świetle znowelizowanych przepisów k.c. o umowie ubezpieczenia. Spór o intencje ustawodawcy , „Wiadomości Ubezpieczeniowe" 2007, $\mathrm{nr} 7 / 8$, s. 3.

17. Zob. Z. Szymański, Ubezpieczenia następstw nieszczęśliwych wypadków, Warszawa 1980, s. 118; podobnie: Z. K. Nowakowski, A. Wąsiewicz, Prawo ubezpieczeń majqtkowych i osobowych, Warszawa-Poznań 1973, s. 18 ? 
członkowie deklaruja swoje uczestnictwo (np. w drodze tzw. deklaracji przystapienia). Przy czym należy zgodzić się z M. Frasem, że nie tylko umowy ubezpieczenia pracowników stanowią ubezpieczenia grupowe, i o ile grupowa formuła ubezpieczeń w zasadzie narodziła się w zakładach pracy, to jednak współcześnie takie ubezpieczenia pracowników nie różnią się zasadniczo od innych empirycznie ukształtowanych typów ubezpieczenia grupowego, np.umów ubezpieczenia kredytobiorców. ${ }^{18}$ Odwołując się zaś do nomenklatury przyjętej przez twórców PEICL, uwaga poświęcona zostanie umowom grupowego ubezpieczenia typu akcesyjnego, przez którą rozumie się „grupową umowę ubezpieczenia której członkowie grupy zostają objęci wynikającą z niej ochroną ubezpieczeniową na podstawie złożonej deklaracji przystapienia lub z powodu braku odmowy objęcia taką ochroną ubezpieczeniową"19.

Ze względu na konfigurację podmiotową charakterystyczną dla umów ubezpieczenia zbiorowego, nieco uwagi poświęcić należy więc pojęciu „grupy”. Możliwość przystapienia do ubezpieczenia będzie zawsze uzależniona od spełnienia przez potencjalnego ubezpieczonego kryteriów przynależności do tejże grupy, które zostały wskazane w treści umowy ubezpieczenia grupowego. Pojęcie grupy można więc sprowadzić do pewnej zbiorowości, charakteryzującej się pewnymi cechami wspólnymi, które z uwagi na swoją istotę maja prowadzić właśnie do dywersyfikacji ryzyka (którego ocena dokonywana jest przez ubezpieczyciela wobec grupy, jako całości ${ }^{20}$ ), a w konsekwencji do zmniejszenia obciążenia ekonomicznego z tytułu składki ubezpieczeniowej. Cechy te, będące jednocześnie wyznacznikiem poziomu badanego ryzyka ubezpieczeniowego, są kluczowe dla oceny, które z wyłączeń lub ograniczeń odpowiedzialności ubezpieczyciela wyrażonych w ogólnych warunkach ubezpieczeń uznać będzie można za dopuszczalne, jako wynikające z natury stosunku prawnego tego typu (zastrzeżone na zasadzie art. $353^{1}$ k.c.), a które za zmierzające do obejścia prawa bądź niedozwolone z uwagi na aktualizację dyspozycji art. $385^{1}$ k.c.

Umowa grupowego ubezpieczenia na życie jest więc umową ubezpieczenia na cudzy rachunek, w której ubezpieczający ubezpiecza życie osoby trzeciej, ale działa przy tym we własnym imieniu. Zgodnie z art. 829 § 2 k.c., w przypadku umowy ubezpieczenia na życie zawartej na cudzy rachunek, ochrona ubezpieczeniowa może być świadczona dopiero od dnia następującego po tym, gdy ubezpieczony wyraził zgodę na objęcie go tą ochroną. Od chwili wyrażenia takiej zgody, zmiana umowy ubezpieczenia na niekorzyść ubezpieczonego lub uposażonego będzie wymagała zgody tego pierwszego. Jak wskazuje Sąd Najwyższy, złożenie tego typu oświadczenia przez ubezpieczonego, statuuje go w ramach stosunku ubezpieczeniowego jako konsumenta w rozumieniu art. $22^{1}$ k.c. ${ }^{21}$ Jest to zastrzeżenie istotne dla dalszych rozważań, szczególnie w kontekście możliwości korzystania przez ubezpieczonego w ramach umowy grupowego ubezpieczenia na życie ze szczególnego reżimu ochrony konsumenckiej.

18. M. Fras, op. cit., s. 64.

19. Art. 1:201 (9) PEICL.

20. E. Stroiński, Ubezpieczenia na życie: teoria i praktyka, Warszawa 2003, s. 284.

21. Wyrok SN z dnia 16 kwietnia 2015 r., III SK 42/14, LEX nr 1710374. 


\section{Granice swobody umów w ramach ubezpieczeń na życie}

Umowa ubezpieczenia na życie cieszy się szczególnym zainteresowaniem ustawodawcy, który w ten sposób dostrzega faktyczną doniosłość konsekwencji odpowiedniego ukształtowania treści tego stosunku zobowiązaniowego dla ubezpieczającego bądź ubezpieczonego. ${ }^{22}$ Chociaż więc już w przepisach ogólnych dotyczạcych ubezpieczeń, ustawodawca statuuje zasadę, wedle której uregulowania kodeksowe w tym zakresie będą mieć charakter norm bezwzględnie obowiązujących (art. 807 k.c.) 23 , to przewidując w dziale III tytułu XXVII regulacje szczególne dla umowy ubezpieczenia na życie właśnie, jeszcze bardziej ogranicza swobodę kontraktową stron, a de facto ubezpieczyciela - w zakresie, w jakim ten precyzuje warunki udzielanej ochrony w ogólnych warunkach umów. Z uwagi na charakter tych ograniczeń, wyprowadzić można wniosek, że w ten sposób ustawodawca zmierza do zapewnienia stosunkowo szerokiej ochrony uprawnionemu z tytułu umowy ubezpieczenia na życie, zaostrzając zasady odpowiedzialności ubezpieczyciela, a nawet liberalizując zakres obowiązków (i konsekwencje ich naruszenia) samego ubezpieczającego lub ubezpieczonego. Regulacja taka jest niewatpliwie odpowiedzią na powszechne oczekiwanie stabilności, przejrzystości i jednolitości ochrony wynikającej z ubezpieczeń na życie, tak aby ich kształt był przystępny dla każdego kontraktującego i odpowiadał uzasadnionym przeświadczeniom co do zakresu otrzymywanej w zamian za opłacanie składek ochrony. ${ }^{24}$ Wynika również ze szczególnego celu tego typu ubezpieczeń, którym jest zapewnienie uposażonym zabezpieczenia finansowego mającego na celu pokrycie potrzeb związanych ze śmiercią ubezpieczonego. Taka finansowa prewencja jest niewątpliwie zjawiskiem pożądanym, a rozwojowi świadomości społecznej w tym zakresie sprzyja prawne usankcjonowanie możliwie jednolitego modelu zakresu ochrony ubezpieczeniowej i zagwarantowanie takiej jego prostoty, która uczyni z umowy ubezpieczenia na życie instrument zabezpieczenia finansowego popularnego także dlatego, że nie wzbudzającego podejrzliwości i gwarantującego oczekiwane rezultaty. Taka motywacja ustawodawcy znalazła odzwierciedlenie także w ustawie o działalności ubezpieczeniowej i reasekuracyjnej, która explicite precyzuje wymagania w zakresie minimalnej treści umowy ubezpieczenia na życie (art. 20 u.d.u.r.; wcześniej art. 13 ustawy o działalności ubezpieczeniowej ${ }^{25}$ ].

22. W tym przedmiocie znamienny jest również fakt publiczonprawnych gwarancji prawidłowej działalności i gospodarki finansowej ubezpieczycieli w sektorze ubezpieczeń na życie wyrażających się m.in. zakazem łączenia działalności w dziale pierwszym (ubezpieczeń na życie) z działalnością w zakresie pozostałych ubezpieczeń (art. 9 ust. 1 u.d.u.r.). Odmienne są również minimalne wymagania finansowe stawiane tworzącym się podmiotom w tych dwu działach (por. m.in. art. 272 u.d.u.r.). Regulacje takie znajdują swoje uzasadnienie w potrzebie zagwarantowania ochronny interesów osób uprawnionych z tytułu ubezpieczeń na życie, w tym uniemożliwienia finansowania bieżącej działalności w zakresie ubezpieczeń majątkowych - zazwyczaj krótkoterminowych - przychodami z ubezpieczeń na życie (tak: M. Krajewski, Art. 829, w: op. cit, Nb. 9).

23. Co samo w sobie jest już istotnym ukłonem w stronę nie trudniącej się profesjonalnie działalnością ubezpieczeniową strony stosunku zobowiązaniowego.

24. Por. Uzasadnienie projektu ustawy o działalności ubezpieczeniowej i reasekuracyjnej, druk sejmowy nr 3644, s. 38-39; ; http://orka.sejm.gov.pl/Druki7ka.nsf/0/C8757DC68795390DC1257EPD004981FE/\%24File/3644-uzasadnienie.docx [dostęp: 15.12.2017]; w szczególności: „Wprowadzenie nowych regulacji jest zatem uzasadnione z uwagi na potrzebę: (...) zlikwidowania dysproporcji w zakresie ochrony klientów rynku kapitałowego i ubezpieczeniowego, wobec zbliżonego charakteru niektórych spośród oferowanych na obu rynkach usług." (s. 38).

25. Ustawa z dnia 22 maja 2003 r. o działalności ubezpieczeniowej. (t.j. Dz. U. z 2015 r. poz. 1206 z późn. zm.). 
Realizując wyżej opisane cele, w art. 834 k.c. istotnie została ograniczona możliwość wyłączenia odpowiedzialności ubezpieczyciela za następstwa okoliczności niepodanych lub nieprawidłowo podanych przy zawieraniu umowy - w szczególności z powodu zatajenia choroby osoby ubezpieczonej. Zarzut z tego tytułu ubezpieczyciel może podnosić bowiem nie dłużej niż do upływu trzech lat od zawarcia umowy ubezpieczenia na życie. Jest oczywiste, że w ubezpieczeniach na życie czynniki związane ze stanem zdrowia ubezpieczonego istotnie determinuja poziom ryzyka ponoszony przez ubezpieczyciela. Stąd też stanowia szczególny aspekt zainteresowania w zakresie ograniczania odpowiedzialności ubezpieczeniowej. Pokusa minimalizacji ryzyka (ergo maksymalizacją zysków zakładu ubezpieczeń) była na tyle duża, że musiała zostać wprost zmiarkowana przed ustawodawcę. W tym kontekście należy również odczytywać art. 815 k.c. chociaż prima facie konstytuuje on szczególne powinności ubezpieczającego i ubezpieczonego (zob. $\S 2^{1}$ ), to w istocie zmierza również do ograniczenia możliwości podnoszenia przez ubezpieczyciela zarzutów związanych z przyczynami zajścia wypadku ubezpieczeniowego jedynie do tych okoliczności, o które sam zapytywał w formularzu oferty albo przed zawarciem umowy w innych pismach. Na unormowaniach art. 815 k.c. doktryna opiera klasyfikację umowy ubezpieczenia jako kontraktu najwyższego zaufania (contractus uberrimae fides) ${ }^{26}$. Zaufanie to należy odczytywać także w kontekście uzasadnionych oczekiwań ubezpieczonego lub ubezpieczającego wobec ubezpieczyciela, co oznacza, że dokonywanie w ogólnych warunkach umów wyłączeń lub ograniczeń odpowiedzialności ubezpieczyciela za następstwa okoliczności, o które ten nie zapytywał, poczytywać należy jako próbę obejścia normy z art. 815 k.c. ${ }^{27}$ W przypadku ubezpieczeń na życie, sankcja niedopełnienia przez ubezpieczającego (ubezpieczonego) tych powinności, na mocy postanowień art. 834 k.c., ulega jeszcze większemu ograniczeniu - ubezpieczyciel nie może skutecznie odmówić wypłaty świadczenia ze względu na to, że przy zawieraniu umowy podano wiadomości nieprawdziwe, w szczególności że zatajona została choroba osoby ubezpieczonej - jeśli od zawarcia umowy do zajścia wypadku ubezpieczeniowego minęły już co najmniej 3 lata. W doktrynie słusznie zauważa się, że art. 834 k.c. jest przejawem szczególnej ochrony prawnej przyznanej ubezpieczonym, a wykładnia prowadząca do skutków innych niż przewidziano w tym przepisie, musi być z góry odrzucona, jako sprzeczna z ustawą ${ }^{28}$.

\section{Dopuszczalność wyłączenia zastosowania art. 815 i 834 k.c. w umowach grupowego ubezpieczenia na życie}

Nie powinno więc budzić wątpliwości, że art. 834 i 815 k.c. zawsze znajdą zastosowanie w przypadku indywidualnych umów ubezpieczenia na życie (a ewentualna sprzeczność postanowień tych umów z wymienionymi przepisami, doprowadzi do nieważności tych pierwszych), jednak stosowanie przywołanych przepisów wprost do stosunków wynikających z umów ubezpieczenia grupowego budzi już kontrowersje. Ubezpieczyciele bowiem, a za nimi przedstawiciele doktryny

26. Zob. m.in. M. Orlicki, Umowa ubezpieczenia, w: System Prawa Prywatnego. Prawo zobowiqzań - część szczegółowa. Tom 8., pod red. J. Panowicz-Lipskiej, wyd. 2, Warszawa 2011, s. 814-815.

27. Zob. m.in. wyrok SO w Łodzi z dnia 22 lutego 2016 r., III Ca 1651/15 oraz wyrok SA w Warszawie z dnia 08 stycznia 2015 r., I ACa 762/14.

28. B. Kęszycka, Art. 834, w: op. cit., pkt. 6. 
opowiadający się za koniecznością istotnej modyfikacji przepisów kodeksu cywilnego w zakresie, w jakim mają one mieć zastosowanie do ubezpieczeń grupowych, podnoszą że w tego rodzaju ubezpieczeniach wyłączenie odpowiedzialności za choroby istniejące przed objęciem ubezpieczonego ochroną zastępuje deklarację ryzyka. Wskazują oni, że ubezpieczyciel dokonuje łącznej oceny ryzyka całej grupy, stąd też badanie indywidualnych cech poszczególnych członków grupy jest bezzasadne w świetle "grupowego" charakteru umowy, a uproszczona procedura oceny ryzyka stanowi istotę tego typy umów. ${ }^{29}$ W tym kontekście, J. Nawracała proponuje by jedynie od decyzji ubezpieczyciela uzależniać, czy konstrukcja danej umowy ubezpieczenia oparta jest na modelu deklaracji ryzyka, czy też na modelu automatycznych wyłączeń odpowiedzialności, przewidzianych w ogólnych warunkach ${ }^{30}$.

W tej argumentacji pomija się jednak fakt, że umowa grupowego ubezpieczenia na życie pozostaje umową ubezpieczenia »na życie«, a natura i istota ochrony świadczonej w tym zakresie nie może zostać całkowicie zignorowana. Ubezpieczający, zawierając umowę ubezpieczenia na życie (jak też ubezpieczony - przystępując do ubezpieczenia) ma na celu zapewnienie finansowania określonych potrzeb powstałych w następstwie swojej śmierci. Są to oczekiwania znajdujace explicite odzwierciedlenie w bezwzględnie obowiązujących przepisach prawa. Nie kwestionując zaś dopuszczalności stosowania, ukształtowanych przez praktykę ubezpieczeń grupowych, należy wskazać, że swoboda umów zawsze znajduje swoje granice w bezwzględnie obowiązujących przepisach prawa (art. $353^{1}$ k.c.). Tymczasem de lege lata naturę tego stosunku prawnego wyznacza przede wszystkim przedmiot ochrony ubezpieczeniowej - życie ubezpieczonego, a nie konfiguracja podmiotów uczestniczących w tym stosunku. Umowa grupowego ubezpieczenia na życie jest ponadto w pierwszej kolejności umową ubezpieczenia na życie, a dopiero w zakresie nie uregulowanym w sposób imperatywny w przepisach rozdziału XVII kodeksu cywilnego, możliwe jest swobodne kształtowanie treści stosunku prawnego, z uwzględnieniem jego natury i specyfiki wynikajaccej z »grupowości» ubezpieczenia.

W tym kontekście indyferentne są argumenty, jakoby przyjęcie takich wniosków zmusiło ubezpieczycieli do kalkulacji składek na wyższym poziomie, a przez to ograniczyło dostęp do ubezpieczeń szerszemu kręgowi ubezpieczających (ubezpieczonych). Jest to zresztą zarzut chybiony, bowiem akceptując badane wyłączenia odpowiedzialności, ochrona ubezpieczeniowa pozostawałaby jedynie iluzoryczna, i tym samym nie spełniałaby funkcji przypisywanej i powszechnie oczekiwanej od ubezpieczeń na życie. Nadto, przytaczane argumenty dotyczące braku konieczności indywidualnej oceny ryzyka przy ubezpieczeniach grupowych są o tyle niekompletne, o ile nie uwzględniają, że ukształtowanie grupy przewidywać powinno właśnie taką odpowiednią dywersyfikację ryzyka, ażeby mimo przejęcia przez zakład ubezpieczeń odpowiedzialności co do zasady w takim samym zakresie jak w przypadku ubezpieczeń indywidualnych, możliwe było zmniejszenie wysokości składki. Ta ekonomiczna korzyść dla ubezpieczonych wynikać powinna jednak nie ze zdecydowanie ograniczonego, zminimalizowanego zakresu odpowiedzialności ubezpieczyciela, ale z rozpiętości grupy objętej ochroną i masowości nawiązanych w ten sposób stosunków ubezpieczeniowych (ergo

29. B. Mrozowska-Bartkiewicz, A. Tarasiuk-Flordowska, Grupowa umowa ubezpieczenia na życie a ocena ryzyka ubezpieczeniowego - problemy praktyczne, „Wiadomości Ubezpieczeniowe” 2013, nr 2, s. 21-33.

30. J. Nawracała, Ograniczenie odpowiedzialności ubezpieczyciela z tytułu ryzyk, które wystapiły przed zawarciem umowy ubezpieczenia ( $n a$ przykładzie klauzuli wpisanej do rejestru niedozwolonych postanowień pod nr 3456), „Wiadomości Ubezpieczeniowe” 2013, nr 1, s. 66-68. 
zdecydowanemu zwiększeniu wpływów ze składek wobec osób objętych z założenia podobnym ryzykiem]. Gdyby przyjać odmienne stanowisko, nic nie stało by na przeszkodzie, by dopuścić takie indywidualne umowy ubezpieczenia na życie, w których kosztem niższej składki, odpowiedzialność ubezpieczyciela ograniczona byłaby w podobny sposób.

Zarzut zaś jakoby przyjęcie wobec umów ubezpieczenia grupowego rygorów art. 815 i 834 k.c. stosowanych wprost rodziło po stronie ubezpieczyciela ryzyko sytuacji zawarcia umowy ubezpieczenia przez osobę posiadającą świadomość, że wypadek ubezpieczeniowy wystapi w okresie ubezpieczenia (np. osobę śmiertelnie chora) ${ }^{31}$, nie wydaje się być przekonującym. Należy mieć bowiem na uwadze pierwotną funkcję konstrukcji ubezpieczeń grupowych, do których istoty należeć miało to, że oceny ryzyka ubezpieczyciel dokonuje przed zawarciem umowy w odniesieniu do grupy jako całości, a więc ze świadomością, że będą wśród jej członków tacy ubezpieczeni, wobec których prawdopodobieństwo wystapienia wypadku będzie bardzo wysokie, jak i tacy - wobec których prawdopodobieństwo to będzie stosunkowo małe ${ }^{32}$.

0 ile należy zgodzić się z teza, jakoby art. 815 k.c. nie nakładał na ubezpieczyciela obowiązku analizy ryzyka przed zawarciem umowy ${ }^{33}$, o tyle przyjąc trzeba również, że zakazuje on wprowadzania do umowy wyłączeń odpowiedzialności odnoszących się do okoliczności, o które ubezpieczyciel teoretycznie mógł zapytać przed zawarciem umowy lub przystapieniem do grupy, ale tego nie uczynił. Definitywność takiej konkluzji w odniesieniu do umów (także grupowego) ubezpieczenia na życie, potwierdza nadto jednoznaczna treść art. 834 k.c.

Stany chorobowe stanowią okoliczności co do zasady niezależne od woli ubezpieczonego. Trudno więc uznać za zgodne z idea ubezpieczeń takie ograniczenia, które w ubezpieczeniach na życie ryzykiem konsekwencji okoliczności tego typu obciążaja samego ubezpieczającego lub ubezpieczonego. ${ }^{34}$ Byłoby to sankcjonowanie tendencji do pozbawienia ubezpieczenia jego podstawowej funkcji, jakajest przeniesienie ryzyka zajścia wypadku ubezpieczeniowego z ubezpieczonego na ubezpieczyciela. Tymczasem należy jej zdecydowanie przeciwstawić treść bezwzględnie obowiązujacych przepisów prawa - art. 815 i 834 k.c.

Stosowanie tego typu wyłączeń narusza zasadę szczególnego zaufania partnerów umowy ubezpieczenia, gdyż ubezpieczyciel pomijający ocenę stanu zdrowia ubezpieczonego przed jego przystapieniem do ubezpieczenia i pomimo tego udzielający mu ochrony, wbrew uzasadnionemu oczekiwaniu ubezpieczonego na wypłatę świadczenia w razie zajścia wypadku ubezpieczeniowego, dopiero na etapie rozpatrywania roszczenia zaskakuje kontrahenta informacja, że ochrona ubezpieczeniowa nie była w tym zakresie udzielana. Takie działanie zakładu ubezpieczeń stanowi „akt nielojalności i złej wiary, która nie zasługuje na ochronę prawna”35.

W tożsamy do ustawodawcy polskiego sposób do omawianego zagadnienia podeszli twórcy Zasad Europejskiego Prawa Ubezpieczeń. Odpowiednikiem art. 834 k.c. jest bowiem art. 17:201 $P \varepsilon I C L^{36}$. Mimo, że umieszczony on został w rozdziale poświęconym ubezpieczeniu na życie właśnie,

31. Ibidem, s. 59.

32. M. Krajewski, Art. 834, w: op. cit., Nb. 4.

33. J. Nawracała, op. cit., s. 68.

34. M. Szczepańska, Funkcje ubezpieczeń na życie, w: Ubezpieczenia na życie. Aspekty prawne, Warszawa 2008.

35. Wyrok SO w Koszalinie z dnia 27 października 2015 r., IC 152/12.

36. Z ta różnica, że możliwość wyłączenia odpowiedzialności ubezpieczyciela za niepodane do jego wiadomości lub nieprawidłowo podane informacje ograniczona została nie do trzech, ale pięciu lat. 
a nie ubezpieczeniom grupowym, zgodnie z art. 18:201 PEICL należy - ale tylko „tam, gdzie to konieczne" - stosować pozostałe postanowienia PEICL do umów akcesyjnego ubezpieczenia grupowego. Mogłyby więc okazać się uzasadnione odstępstwa od modelu deklaracji ryzyka i sankcji wynikających z naruszenia powinności ubezpieczającego (ubezpieczonego), wynikające z natury ubezpieczenia grupowego, jednakże dywagacjom takim kres kładzie wykładnia art. 18:204 PEICL, w świetle którego w razie ustania ochrony z tytułu ubezpieczenia grupowego na życie, „członek grupy ma prawo do ekwiwalentnej ochrony ubezpieczeniowej na podstawie nowej indywidualnej umowy z tym samym ubezpieczycielem wraz z utrzymaniem poprzedniej oceny ryzyka". Oznacza to, że treść indywidualnej umowy w zakresie ochrony ubezpieczeniowej będzie odpowiadać (co do zasady bez żadnych zmian w tym zakresie) ochronie, którą ubezpieczony objęty był jeszcze w ramach umowy grupowej. Skoro zaś treść ta ograniczona jest postanowieniami rozdziału 17 PEICL, to oznacza, że i w przypadku umów grupowego akcesyjnego ubezpieczenia na życie, postanowienia tego rozdziału w zakresie świadczonej ochrony znajdują zastosowanie wprost i w pierwszej kolejności ${ }^{37}$. Wniosek taki powinien odnaleźć explicite odzwierciedlenie w postanowieniach ogólnych rozdziału 18 PEICL. Odpowiada on postulatowi »prostoty« ubezpieczeń na życie (niezależnie od sposobu objęcia ochroną ubezpieczeniową ubezpieczonego). Są one bowiem z jednej strony dedykowane szerokiemu gronu konsumentów, niezależnie od ich wykształcenia, zamożności i poziomu świadomości prawnej. Z drugiej strony, stanowią instytucję z ugruntowanąjuż „tradycją” i narosłymi wokół niej uzasadnionymi oczekiwaniami co do poziomu udzielanej ochrony - jej swoistemu, powszechnemu zestandaryzowaniu. W długofalowej perspektywie, przejrzystość warunków i poczucie stabilności świadczonej ochrony, służą przecież obu stronom - zwiększając zaufanie konsumentów wobec ubezpieczycieli, wzmagaja popyt na ten rodzaj finansowego zabezpieczenia ekonomicznych interesów gospodarstw domowych, a więc i przychody z tytułu składek.

\section{Wyłączenie odpowiedzialności ubezpieczyciela za następstwa tzw. choroby istniejącej jako klauzula niedozwolona}

\subsection{Indywidualne uzgodnienie umowy}

W świetle orzecznictwa Sądu Najwyższego, nawet jeśli postanowienia ogólnych warunków ubezpieczenia grupowego zostały ustalone w toku indywidualnych negocjacji przez ubezpieczającego z ubezpieczycielem, nie prowadzi to do pozbawienia ubezpieczonego prawa do ich kwestionowania w oparciu o art. $385^{1}$ k.c. (jako klauzul niedozwolonych), a nadto nie dyskwalifikuje możliwości oceny w relacjach między ubezpieczonym a ubezpieczycielem tych ogólnych warunków jako wzorca umownego w rozumieniu art. 384 k.c. ${ }^{38}$ Pogląd ten pozostaje w doktrynie bardzo kontrowersyjny ${ }^{39}$ i z uwagi na ramy niniejszego opracowania nie będzie możliwe poświęcić wystarczajaco uwagi wszelkim argumentom podniesionym zarówno przez aprobujących glosatorów jak

37. Por. J. Basedow (red.), Principles of European Insurance Contract Law (PEICL), Verlag Otto Schmidt, Köln 2016, s. 357-358, 361-364; por. również M. Fras, Prawo jednolite o umowie ubezpieczenia grupowego; w: op. cit., pkt 3.3.2 oraz 3.3.5; K. Pacuła, Przepisy wymuszajace swoje zastosowanie jako instrument ochrony „strony słabszej” umowy ubezpieczenia, „Przegląd Prawa Prywatnego Międzynarodowego” 2014, nr 15, s. 44-46.

38. Wyrok SN z dnia 12 marca 2015 r., I CSK 165/14, BSN 2015, Nr 5.

39. J. Pokrzywniak, op. cit., $\mathrm{Nb} 2$. 
i krytyków takiego stanowiska. W kontekście i na potrzeby poruszanego w niniejszym artykule problemu, autorowi trudno jednakże zgodzić się z argumentem podniesionym na uzasadnienie konieczności kwalifikacji OWU w ubezpieczeniach grupowych jedynie w oparciu o relacje łączące ubezpieczającego z ubezpieczycielem przez M. Kondka, który wskazuje, że niezależnie od treści umowy ubezpieczony pozostaje i tak w lepszej sytuacji, gdyby na jego rzecz nie zawarto umowy ubezpieczenia, bowiem jeśli uzna że jej postanowienia są dla niego niekorzystne, może po prostu z nie skorzystać z ochrony ubezpieczeniowej ${ }^{40}$.

0 ile bowiem to ubezpieczający jest zawsze i jedynie zobowiązany do zapłaty składki ubezpieczeniowej w ramach ubezpieczeń na cudzy rachunek, o tyle w praktyce ciężar ekonomiczny składki, w drodze odrębnej umowy, przenoszony jest najczęściej na ubezpieczonego ${ }^{41}$. Rzeczywista swoboda ubezpieczonego w tym zakresie w praktyce obrotu ulegała znaczącym ograniczeniom - ubezpieczenia grupowe szczególnie popularne są w kanale bancassurance, jako forma zabezpieczenia wierzytelności banku z tytułu udzielonego kredytu na wypadek śmierci kredytobiorcy. Przystapienie do nich przed 1 lipca 2016 r. ${ }^{42}$ było bardzo często jednym z koniecznych warunków uzyskania kredytu - swoboda kontraktowa kredytobiorcy-ubezpieczonego była więc znacznie ograniczona. Jak się wydaje - nie można przy tym zarzucić mu, jako konsumentowi braku dostatecznej ostrożności i uwagi ${ }^{43}$, skoro działał wobec kontrahentów mieniających się jako instytucje zaufania publicznego ${ }^{44}$. W doktrynie wszakże nadal podnosi się, że umowa ubezpieczenia stanowi kontrakt najwyższego zaufania stron ${ }^{45}$.

Zawężająca - przeprowadzona w opozycji do przywołanego stanowiska Sądu Najwyższego interpretacja doprowadziłaby więc de facto do pozbawienia ubezpieczonych istotnego instrumentu

40. M. Kondek, op. cit., Nb 6.

41. Uznaje się to zresztą w doktrynie za rozwiązanie dopuszczalne - por. D. Maśniak, Specyfika ubezpieczeń grupowych w świetle ustawy o działalności ubezpieczeniowej i reasekuracyjnej i kodeksu cywilnego, w: „Gdańskie Studia Prawnicze”, Gdańsk 2016, nr 2. s. 281-294; podobnie: M. Gumularz, Ubezpieczenia na cudzy rachunek - pozycja prawna konsumenta (ubezpieczonego), w: „Radca Prawny”, Warszawa 2013, nr 6. s. 12-15; por. również: wyrok SN z dnia 12 września 2013 r. IV CSK 91/13, niepubl.

42. Z uwagi na wejście w życie ustawy z dnia 23 marca 2017 r. o kredycie hipotecznym oraz o nadzorze nad pośrednikami kredytu hipotecznego i agentami (Dz.U. 2017 poz. 819) praktyki takie zostały ograniczone. Przepisy tej ustawy nie stoja jednak na przeszkodzie uzależniania przez banki możliwości skorzystania z korzystnych warunków kredytowania (np. pomniejszona prowizja albo marża oprocentowania) od przystapienia do grupowych umów ubezpieczenia. W sytuacji zaś, w której kredyt udzielany będzie tylko jednej osobie, albo wielu osobom ale dochody jednej z nich stanowić będą co najmniej 75\% dochodów branych pod uwagę przy ocenie zdolności kredytowej, instytucja kredytowa nadal będzie mogła skutecznie uzależnić udzielenie kredytu od zabezpieczenia wierzytelności cesją z umowy ubezpieczenia, tyle tylko, że uwzględniając przytoczoną regułę, co do zasady nie będzie mogła wskazać ubezpieczyciela. Z tych przyczyn jednak grupowe ubezpieczenia na życie nadal są szeroko wykorzystywane w sektorze bancassurance.

43. Por. wyrok TS UE z dnia 6 lipca 1995 r. w sprawie C-470/93, Verein gegen Unwesen in Handel und Gewerbe Köln e.V. v. Mars GmbH, ECR 1995, s. I-01923 - i przytoczone tam orzecznictwo.

44. Pkt 3 Postanowień Ogólnych Kodeksu Etyki Bankowej (Zasady Dobrej Praktyki Bankowej) przyjętego na XXV Walnym Zgromadzeniu ZBP w dniu 18 kwietnia 2013 r., Związek Banków Polskich, Warszawa 2013;

https://zbp.pl/public/repozytorium/dla_konsumentow/rekomendacje/KEB final_WZ.pdf [dostęp: 14.01.2018] oraz pkt 1 Postanowień Ogólnych Zasad Dobrych Praktyk Polskiej Izby Ubezpieczeń przyjętych na Walnym Zgromadzeniu PIU w dniu 8 czerwca 2009 roku, Polska Izba Ubezpieczeń, Warszawa 2009; https://piu.org. pl/zasady-dobrych-praktyk/ [dostęp: 14.01.2018].

45. Zob. przyp. 26 . 
ochrony ich interesów mimo, że ich sytuacja faktyczna odpowiadała celom funkcjonalnym, jakie leżały u podstaw unijnej regulacji przepisów dot. nieuczciwych warunków umownych ${ }^{46}$. W końcu odnotować należy, że w przypadku ochrony ubezpieczeniowej świadczonej na warunkach wynikających z OWU przewidujących wyłączenie odpowiedzialności ubezpieczyciela typu pre-existing medical conditions, bank wydaje się uzyskiwać jedynie iluzoryczne zabezpieczenie, które nie może sprostać wymogom wynikającym z Rekomendacji S Komisji Nadzoru Finansowego ${ }^{4 ?}$. Tymczasem przecież to bank w przypadku grupowych ubezpieczeń na życie swoich kredytobiorców odpowiada za wybór oferty i ewentualne uzgodnienia w zakresie świadczonej ochrony ubezpieczeniowej, a więc również wyłączeń odpowiedzialności ubezpieczyciela.

\subsection{Zagadnienie głównego świadczenia stron w umowie ubezpieczenia}

Sposób rozumienia pojęcia „główne świadczenie stron” nie jest w doktrynie jednolity. Niektórzy jej przedstawiciele sugerujajego autonomiczność znaczeniową od pojęcia postanowień przedmiotowo istotnych (essentialia negotii] ${ }^{48}$, większość jednak ${ }^{49}$ - a za nimi także Sąd Najwyższy ${ }^{50}$ co do zasady uznaje pojęcia te za tożsame znaczeniowo, chociaż jednocześnie zastrzega konieczność dokonywania zawężającej wykładni pojęcia, którym ustawodawca wprost za prawodawcą unijnym, posługuje się w art. $385^{1} \mathrm{zd}$. 2. k.c.

Stąd też ubezpieczyciele w postępowaniach dotyczących klauzul ograniczających zakres świadczonej ochrony ubezpieczeniowej, staraja wykazać jednoznaczność ich sformułowania, a przez to odeprzeć ich kontrolę w świetle art. 3851 k.c. jako postanowień określających główne świadczenie stron. W tym celu szeroko korzystają z tzw. teorii ryzyka, w świetle której świadczeniem ze strony ubezpieczyciela nie jest zapłata określonej sumy pieniężnej, dokonywana tylko wówczas gdy ziści się warunek zawarty w umowie (zajdzie wypadek ubezpieczeniowy), ale samo przejęcie ryzyka, tj. stan nieustannej gotowości do spełnienia tego świadczenia pieniężnego w razie materializacji określonego umową niebezpieczeństwa ${ }^{51}$. Skoro więc głównym świadczeniem ubezpieczyciela jest ponoszenie ryzyka za zajście zdarzeń objętych ochroną ubezpieczeniową, to postanowienia umowne wyłączające tę odpowiedzialność dotyczą tak rozumianego głównego świadczenia stron.

0 ile do teorii ryzyka, jako najtrafniej charakteryzującej przedmiot świadczenia ubezpieczyciela w ramach umowy ubezpieczyciela, należy się przychylić, o tyle z tak przeprowadzona w oparciu o nią argumentacją, nie sposób już się zgodzić. Sam fakt, że pewne postanowienie „dotyczy”

46. Por. motywy 5, 8 a w szczególności 15 dyrektywy Rady 93/13/EWG z dnia 5 kwietnia 1993 r. w sprawie nieuczciwych warunków w umowach konsumenckich (Dz. U. UE. L. z 1993 r. Nr 95, str. 29 z późn. zm.).

47. Rekomendacja S dotyczqca dobrych praktyk w zakresie zarzqdzania ekspozycjami kredytowymi zabezpieczonymi hipotecznie, Komisja Nadzoru Finansowego, Warszawa 2013, dostępna online: https://www.knf.gov. $\mathrm{pl} / \mathrm{knf} / \mathrm{pl} / \mathrm{komponenty} / \mathrm{img} /$ Rekomendacja___18-01-2011_25296_2_25296.pdf [14.01.2018]

48. Tak: F. Zoll, Prawo bankowe. Komentarz, t. II, Komentarz do art. 92A-194, Kraków 2005, s. 314.

49. Tak. m.in. EWieczorek, Art. 385(1), w: Komentarz do niektórych przepisów ustawy - Kodeks cywilny, w: Prawo ubezpieczeń gospodarczych. Tom II. Komentarz, pod. red. M. Gilcza, M. Serwach, wyd. II, SIP LEX, 2010, pkt. V; również: M. Bednarek, Wzorce umów, w: System Prawa Prywatnego. Prawo zobowiqzań - część ogólna. Tom 5, pod red. E. Łętowskiej, wyd. 2, Warszawa 2013, s. 757 oraz: A. Olejniczak, Art. 385(1), w: Kodeks cywilny. Komentarz. Tom III. Zobowiqzania - część ogólna, pod red. A. Kidyby, wyd. II, SIP LEX, Warszawa 2014, pkt. 6.

50. Wyrok SN z dnia 08 czerwca 2004r., I CK 635/03.

51. Tak: M. Orlicki, op. cit., s. 838-840. 
głównego świadczenia stron, nie sprawia, że jest to postanowienie „określające” te świadczenia. Z orzecznictwa Trybunału Sprawiedliwości Unii Europejskiej wyłania się jasny obraz postanowień umowy określających główne świadczenie stron, jako tych, „które określaja podstawowe świadczenia w ramach danej umowy i które z tego względu charakteryzują tę umowę" ${ }^{2}$. Nadto, TS UE wskazuje w innym - niezwykle istotnym dla niniejszych rozważań z uwagi na tożsamość podjętej problematyki - orzeczeniu, że „warunki, które wykazują charakter posiłkowy względem warunków definiujących samą istotę stosunku umownego, nie mogą być objęte pojęciem „głównego przedmiotu umowy" w rozumieniu tego przepisu"53.

Niezależnie jednak od przyjętej teorii w przedmiocie świadczenia charakterystycznego ubezpieczyciela, kontrola postanowień ograniczających zakres odpowiedzialności będzie odbywać się zawsze na zasadach ogólnych wyrażonych w art. $385^{1} \S 1$ zd. 1 k.c. Jeśli bowiem wyjść od teorii świadczenia, trzeba dojść do wniosku, że skoro głównym świadczeniem ubezpieczyciela jest wypłata określonego świadczenia w razie zajścia zdarzenia ubezpieczeniowego, to postanowienia takie w żadnej mierze nie charakteryzują tego świadczenia ${ }^{54}$. Nawet zaś przy przyjęciu, że głównym świadczeniem ubezpieczyciela wobec ubezpieczonego jest przejęcie ryzyka, to i tak postanowienia ograniczające zakres odpowiedzialności jedynie dotyczą świadczenia głównego, a nie określajaje $e^{55}$.

W tym zakresie na aprobatę zasługuje rozwiązanie tego problemu przyjęte w Zasadach Europejskiego Prawa Ubezpieczeń. W art. 2:304 PEICL przesądzono bowiem wprost, że ocenie abuzywności postanowień ogólnych warunków podlegaja przede wszystkim postanowienia, „które ograniczają lub zmieniają zakres ochrony ubezpieczeniowej".

\subsection{Sprzeczność z dobrymi obyczajami i rażące naruszenie interesów konsumenta}

Należy zgodzić się z dominującym stanowiskiem wyrażanym w judykaturze ${ }^{56}$, że postanowienia ogólnych warunków umów wyłączające odpowiedzialność ubezpieczyciela za wypadki ubezpieczeniowe powstałe pośrednio lub bezpośrednio na skutek urazu czy chorób rozpoznanych, zdiagnozowanych lub po prostu istniejących przed objęciem ubezpieczonego ochrona ${ }^{57}$, rażąco naruszają interesy konsumentów, bowiem dokonują zbyt daleko idącej modyfikacji odpowiedzialności ubezpieczyciela wobec uzasadnionego, oczekiwanego przez konsumenta poziomu ochrony.

52. Wyrok TS UE z dnia 30 kwietnia 2014 r., Árpád Kásler i Hajnalka Káslerné Rábai v. OTP Jelzálogbank Zrt, C-26/13, ZOTSiS 2014/4/I-282, pkt. 61.

53. Wyrok TS UE z dnia 23 kwietnia 2015 r. w sprawie C-96/14, Jean-Claude Van Hove v. CNPAssurances SA, pkt 33 i 3 ?.

54. Wyrok SO w Koszalinie z dnia 27 października 2015 r., IC 152/12

55. Wyrok SA w Warszawie z dnia 19 czerwca 2013 r., VI ACa 1494/12.

56. Tak: wyrok SA w Warszawie z dnia 12 czerwca 2012 r., XVII AmC 1039/09; wyrok SA w Warszawie z dnia 08 stycznia 2015 r., I ACa 762/14; wyrok SA w Warszawie z dnia 19 czerwca 2013 r., VI ACa 1494/12; wyrok S0 w Częstochowie z dnia 17 maja 2012 r. , I C 281/11; wyrok S0 w Łodzi z dnia 22 lutego 2016 r., III Ca 1651/15 oraz orzeczenia przywołane w przyp. 1; odmiennie: wyrok SA w Warszawie z dnia 13 lutego 2015 r., I ACa 692/14.

57. Przykładowo SOKiK zakwestionował postanowienie o treści: „W okresie sześciu miesięcy od rozpoczęcia ochrony ubezpieczeniowej, Zakład Ubezpieczeń nie ponosi odpowiedzialności i jest zwolniony z obowiązu wypłaty świadczenia należnego z tytułu śmierci Ubezpieczonego, jeżeli zdarzenie to nastapi pośrednio lub bezpośrednio na skutek urazu, choroby somatycznej lub psychicznej rozpoznanych przed objęciem Ubezpieczonego ochroną ubezpieczeniowa”. 
Przyjęcie dopuszczalności takiego rozwiązania prowadziłoby do sankcjonowania sytuacji, w której ubezpieczony przez wiele lat pobierałby od ubezpieczającego składkę ubezpieczeniową, jednocześnie nie dokonując oceny ryzyka chociażby w drodze ankiety czy wywiadu lodpowiedź na zadawane pytania mogłaby przynajmniej potencjalnie ukierunkować ubezpieczonego na istotność pewnych okoliczności w świetle granic świadczonej mu ochrony ${ }^{58}$ ], a następnie uchyliłby się od odpowiedzialności, podnosząc zarzut, że wypadek ubezpieczeniowy był skutkiem rozwijającej się od lat choroby. ${ }^{59}$

Dopuszczalność tego typu wyłączeń rodziłaby pokusę, by ubezpieczyciel, zamiast zadawać sobie trud rozeznania w sytuacji zdrowotnej ubezpieczonego, mógłby poprzestać na ogólnym wyłączeniu swojej odpowiedzialności za zdarzenia, które pozostają w związku z chorobami istniejącymi przed datą zawarcia umowy. Co więcej, postanowienia o tożsamym skutku powodowałyby wyłączenie odpowiedzialności ubezpieczyciela nawet za takie choroby, o których sam ubezpieczony mógł nie wiedzieć w chwili zawarcia umowy. Wszakże ich diagnoza nastapić mogła w okresie, którego ubezpieczony nie obejmuje swoją świadomością (np. wczesne dzieciństwo) albo dopiero po dniu przystapienia do ubezpieczenia. Posłużenie się bowiem w kwestionowanych postanowieniach pojęciem „chorób istniejących” powoduje objęcie nimi również takich stanów chorobowych, które obiektywnie „tkwiły” w organizmie ubezpieczonego, ale nie zostały medycznie rozpoznane ${ }^{60}$. Tymczasem już samo wyłączenie ochrony ubezpieczeniowej z uwagi na sytuacje, na które ubezpieczony nie ma w ogóle żadnego wpływu jest niewątpliwie sprzeczne z dobrymi obyczajami i rażąco narusza interesy ubezpieczonego. Przyznanie postanowieniom tego typu przymiotu skuteczności, prowadzi do sytuacji, w której w zasadzie każda osoba z jakimikolwiek zdiagnozowanymi chorobami, przystępując do umowy uzyskiwałaby jedynie iluzoryczną ochronę pomimo regularnego opłacania składki ${ }^{61}$. Dopuszczając model ochrony wynikający z omawianych postanowień, należałoby zaakceptować stan rzeczy, w którym ubezpieczony ponosiłby przez cały okres trwania ubezpieczenia ryzyko zajścia trudnego do przewidzenia zdarzenia w postaci rozwinięcia się istniejącej choroby, aż do stanu odpowiadającemu wypadkowi ubezpieczeniowemu, przy jednoczesnej bierności ubezpieczyciela w zakresie aktywnego szacowania ryzyka ${ }^{62}$.

\section{Skutki prawidłowej kwalifikacji prawnej}

O ile przedstawione wyżej argumenty zachowują swoją aktualność, a poczynione przez judykaturę uwagi aksjologiczne należy w pełni podzielić, o tyle za nieprawidłową należy uznać ocenę dokonywaną w oparciu o zarzut abuzywności (art. $385^{1}$ k.c.) postanowień wzorca. Słusznie bowiem, w każdej z przytoczonych spraw sądy dostrzegały istotną rozbieżność pomiędzy przepisami ustawy - art. 815 i 834 k.c., a modelem ochrony wyłaniającym się z postanowień ogólnych warunków ubezpieczeń dopuszczających wyłączenie odpowiedzialności ubezpieczyciela za tzw. choroby istniejące. Błędnie jednak przyjęły, że przepisy te jedynie kształtuja pewien normatywny

58. Wyrok SA w Warszawie z dnia 12 czerwca 2012 r., XVII AmC 1039/09.

59. Wyrok SA w Warszawie z dnia 08 stycznia 2015 r., I ACa 762/14.

60. Wyrok SA w Warszawie z dnia 19 czerwca 2013 r., VI ACa 1494/12.

61. Wyrok SO w Częstochowie z dnia 17 maja 2012 r. , IC 281/11.

62. Wyrok SO w Łodzi z dnia 22 lutego 2016 r., III Ca 1651/15. 
model zakresu ochrony ubezpieczeniowej, czyniąc go tylko punktem odniesienia, uznając za stan wzorcowy, pożądany (a nie wymagany) przez ustawodawcę.

W świetle jednak uchwały Sadu Najwyższego z dnia 13 stycznia 2011 r. $^{63}$, postanowienie umowy sprzeczne z bezwzględnie obowiązującym przepisem rangi ustawowej nie może być uznane nawet mimo spełnienia wszelkich przesłanek ku temu - za niedozwolone postanowienie umowne w rozumieniu art. $385^{1} \S 1$ k.c. Postanowienie takie będzie więc po prostu nieważne (art. 58 § 1 k.c.), zaś art. 385 k.c. nie może być traktowany jako przepis, który przewiduje inny skutek w rozumieniu art. 58 § 1 in fine k.c. ${ }^{64}$ Uchwała ta spotkała się co do zasady z aprobatą doktryny ${ }^{65}$, choć znalazły się również głosy odmienne ${ }^{66}$, akcentujące rolę funkcjonalnych założeń reżimu wzorców umownych, a przede wszystkim kwestię przystępności przyjętego modelu kontroli dla konsumentów i zgodności tak poprowadzonej wykładni z dyrektywą 93/13/EWG6?.

Dominujące w chwili obecnej stanowisko $w$ doktrynie ${ }^{68}$ również przyznaje sankcji nieważności pierwszeństwo przed sankcją niezwiązania konsumenta postanowieniem umownym stosownie do art. $385^{1}$ k.c. De lege lata jest to jedynie dopuszczalna wykładnia i nie stoi jej na przeszkodzie zasada efektywności prawa unijnego, ani treść i cel dyrektywy 93/13/EWG. Wniosek taki należy wyprowadzić z orzecznictwa Trybunału Sprawiedliwości UE, w świetle którego to zasady prawa wewnętrznego przesądzają o możliwości dalszego trwania stosunku prawnego po eliminacji z niego postanowień niedozwolonych. ${ }^{69} \mathrm{~A}$ maiorem ad minus, skoro Trybunał dopuszcza sytuację, w której bezwzględnie obowiązujące normy prawa krajowego doprowadzą do unieważnienia całej umowy, to trudno przyją́, że prawo europejskie stoi na przeszkodzie pozbawienia skuteczności kwestionowanego przez konsumenta postanowienia wzorca nie w drodze sankcji bezskuteczności, ale bezwzględnej nieważności.?

63. Uchwała SN z dnia 13 stycznia 2011 r., III CZP 119/10, OSNC 2011/9/95.

64. Poglad prawny wyrażony $w$ ww. uchwale został potwierdzony w wyroku SN z dnia 20 stycznia 2011 r., I CSK 218/10, Monitor Prawniczy 2011, Nr 18, s. 99.

65. T. Szanciło, Glosa do uchwały SN z dnia 13 stycznia 2011 r., III CZP 119/10, „Glosa” 2012, Nr 2, s. 71-75; M. Sieradzka, Glosa do uchwały SN z dnia 13 stycznia 2011 r., III CZP 119/10, System Informacji Prawnej LEX, 2011.

66. Tak: P. Gorzko, Glosa do uchwały SN z dnia 13 stycznia 2011 r., III CZP 119/10, System Informacji Prawnej LEX, 2012. Wskazane przez autora argumenty należy uznać za nietrafne w szczególności w zakresie, w jakim kwestionował on zgodność skutku sankcji nieważności umowy na wypadek dokonania kwalifikacji zaproponowanej w uchwale SN z przepisami dyrektywy 93/13/EWG. Dopuszczalność stosowania przez prawo krajowe takich sankcji potwierdził bowiem, że to prawo krajowe rozstrzyga o możliwości dalszego obowiązywania umowy po eliminacji z niej postanowień niedozwolonych - zob. wyrok TS UE z dnia 14 czerwca 2012 r., Banco Espanol de Crédito SA, C 618/10, Z0TSiS 2012/6/I-349, pkt. 65. Argumenty celowościowe zaś nie uwzględniają w dużej mierze pozakodeksowych źródeł roszczeń konsumentów - np. przewidzianych w art. 12 ustawy z dnia 23 sierpnia 2007 r. o przeciwdziałaniu nieuczciwym praktykom rynkowym (t.j. Dz. U. z 2017 r. poz. 2070).

67. Dyrektywa Rady 93/13/EWG z dnia 5 kwietnia 1993 r. w sprawie nieuczciwych warunków w umowach konsumenckich (Dz. U. UE. L. z 1993 r. Nr 95, str. 29 z późn. zm.); dalej jako „dyrektywa 93/13/EWG”.

68. Tak: M. Bednarek, op. cit., s. 773; E. Łętowska, K. Osajda, Zbieg norm prawa cywilnego, w: System Prawa Prywatnego. Prawo cywilne - część ogólna. Tom I, pod red. M. Safjana, Warszawa 2012, s. 648; W. Popiołek, art. 3851, w: Komentarz do kodeksu cywilnego, t. I, pod red. K. Pietrzykowskiego, Warszawa 2015, Nb 13.

69. Wyrok TS UE z dnia 14 czerwca 2012 r., Banco Espanol de Crédito SA, C 618/10, Z0TSiS 2012/6/I-349.

70. Wạtpliwości budzić może jedynie sposób interpretacji art. 58 § 3 in fine k.c. Problem ten wyeliminować można jednak w drodze odpowiedniej wykładni, zmierzającej przede wszystkim do zapewnienia równowagi kontraktowej stron stosunku prawnego, a w ostateczności do zastosowania art. 5 k.c. 
0 ile bowiem celowościowym argumentom podnoszonym w tej materii przez część przedstawicieli doktryny nie można odmówić aksjologicznej słuszności, o tyle trzeba je odczytywać raczej w kategorii postulatów de lege ferenda ${ }^{71}$. Tak też we wcześniejszych publikacjach E. Łętowska, podkreślała służebność prawnych kwalifikacji umożliwiających osiągnięcie realnego skutku ochrony konsumentów, co w efekcie w razie zbiegu norm nie powinno obligować sądu do wyboru jednej tylko drogi urzeczywistnienia tej ochrony i wyboru jednego tylko wariantu kwalifikacji prawnej, ale dawać możliwości wyboru opcji między różnymi instrumentami prawnymi służącymi ochronie interesu zagrożonego przez to samo zdarzenie ${ }^{22}$. W obecnym stanie prawnym jednak zarówno sprzeczność postanowień umowy z bezwzględnie obowiązującymi przepisami prawa, jak i - co do zasady - ich abuzywność ${ }^{73}$, sąd musi uwzględniać z urzędu, toteż stosowanie algorytmu wskazanego w uchwale Sąu Najwyższego nie powinno prowadzić do nadmiernych niedogodności proceduralnych dla konsumentów. Wydaje się, że w niektórych przypadkach przeciwnie, służyć może pewności prawa i a priori sankcjonować nieuczciwe działania silniejszej strony stosunku prawnego, bez badania - pozostawiających zawsze pewien margines oceny i opierających się na kazuistycznie wyważanych interesach - przesłanek abuzywności. Co więcej, zapewni w efekcie szerszą ochronę, bowiem obejmującą również kontrahentów, co do których zastosowanie art. $385^{1}$ k.c. nie będzie możliwe.

Z tych też przyczyn nie można zgodzić się z dominującą w orzecznictwie tezą o abuzywności postanowień ogólnych warunków grupowych ubezpieczeń na życie wyłączających odpowiedzialność ubezpieczyciela za wypadki ubezpieczeniowe wynikające z chorób istniejących (bądź zdiagnozowanych) w okresie przed objęciem ubezpieczonego ochrona. Sądy w każdej analizowanej sprawie dostrzegały istotną rozbieżność między modelem ochrony wyłaniającym się z uwzględniania takich postanowień a przepisami art. 815 i w szczególności art. 834 k.c., mimo to ostatecznie odmawiając im zastosowania nie na podstawie art. 58 k.c., ale właśnie art. $385^{1}$ $\S 1$ k.c. Chociaż skutki dla skarżących w toku tzw. kontroli incydentalnej będą co do zasady identyczne, to ukształtowana w ten sposób linia orzecznicza nastręcza pewnych dodatkowych trudności i w sposób nieuzasadniony zawęża zakres sankcjonowania takich postanowień - przede wszystkim z uwagi na konieczność wykazywania przesłanek abuzywności przez skarżących. Należy bowiem zauważyć, że jedynie w zakresie ewentualnego wykazania indywidualnego uzgodnienia badanego warunku umownego, ustawodawca przerzucił ciężar dowodu na przedsiębiorcę (art. $385^{1}$ § 4 k.c.). Co prawda, jak wskazano wcześniej, sąd samodzielnie, w toku postępowania zobowiązany jest, o ile zgromadzony materiał dowodowy mu na to pozwala ${ }^{74}$, z urzędu dokonywać kontroli postanowień wzorca pod kątem ich ewentualnej abuzywności i wyciagać z niej takie skutki prawne, które spowodują, że konsument nie będzie nimi związany, jednakże możliwość dokonania takiej oceny uzależniona będzie de facto od pewnego ukierunkowanego działania skarżącego, który a priori przedstawi okoliczności stanu faktycznego (a być może nawet przedłoży

71. Przydatna w tym przedmiocie może okazać się analiza rozwiązań normatywnych i koncepcji doktryny niemieckiej, w szczególności w zakresie tezy „podwójnego skutku” w prawie.

72. E. Łętowska, Zbieg norm w prawie cywilnym, Warszawa 2002, s. 71 i 72.

73. Por. wyrok SN z dnia z 14 lipca 2017 r.; II CSK 803/16; wyrok TS UE z dnia 27 czerwca 2000 r., w połączonych sprawach C - 240/98 oraz C-244/98, Océano Grupo Editorial and Salvat Editores, ECR 2000/6/I-4941, pkt 35; wyrok TS UE z dnia 1października 2015 r. w sprawie C-32/14, ERSTE Bank Hungary Zrt. v. Attila Sugár, ZOTSiS 2015/10/l-637, pkt 41.

74. Wyrok TS UE z dnia 9 lipca 2015 r. w sprawie C-348/14, Maria Bucura przeciwko SC Bancpost SA, EU:C:2015:447, pkt 41-44 oraz pkt 2 sentencji. 
pewne dowody], stanowiące punkt wyjścia dla takiej kontroli. W sytuacji sprzeczności postanowień umownych z bezwzględnie obowiązującymi przepisami ustawy konieczność taka odpada, a sąd dokonuje analizy stanu prawnego, nie sięgając co do zasady do okoliczności faktycznych sprawy. Na marginesie można zauważyć, że dokonywanie takiej kwalifikacji prawnej konstytuuje przeświadczenia o dostępności ochrony w tym zakresie jedynie wobec podmiotów, którym służy zarzut z art. $385^{1}$ k.c. 0 ile w przedmiocie ubezpieczeń na życie argument ten będzie nieistotny, o tyle w przedmiocie innych rodzajów ubezpieczeń, których ogólne warunki będą zawierać postanowienia zmierzające do obejścia art. 815 k.c. może okazać się ważki.

Faktem zaś jest, że w świetle wspomnianej uchwały, postanowienia ogólnych warunków - przynajmniej w zakresie, w jakim odnosiły się do ubezpieczeń na życie - zakwestionowane przez Sąd Ochrony Konkurencji i Konsumentów nie powinny być przedmiotem wpisu do Rejestru Klauzul Niedozwolonych. Gdyby jednak jednolicie w orzecznictwie przyjęto sankcję nieważności postanowień tego typu, efektywność ochrony zapewnianej kontrahentom nie byłaby zagrożona, a w świetle uwag powyższych, droga do egzekwowania roszczeń nieco ułatwiona. W dłuższej perspektywie zaś przyjęcie takiej kwalifikacji mogłoby odnieść skutek dalej idący, bowiem uniwersalność sankcji bezwzględnej nieważności wobec dosyć wąskich granic prawomocności materialnej orzeczenia o wpisie postanowienia do rejestru ${ }^{75}$, wydaje się bardziej odstraszająca i w ten sposób pełniąca prewencyjne funkcje w obrocie. W szczególności z uwagi na fakt, że sam Rejestr Klauzul Niedozwolonych w związku z nowelizacją ustawy o ochronie konkurencji i konsumentów ${ }^{76}$ od 17 kwietnia 2016 roku przestał funkcjonować w dotychczasowym kształcie. Wobec zmian modelu tzw. abstrakcyjnej kontroli postanowień wzorców umownych z sądowego na administracyjny, utracił on na swym znaczeniu i doniosłości praktycznej.

\section{Ubezpieczenia grupowe (na życie) - wnioski de lege ferenda}

Przedstawiona problematyka ujawniła pewne mankamenty regulacji ustawowej, a raczej potrzebę unormowania tak popularnych ubezpieczeń grupowych. To bowiem w większości z uwagi na »grupowy« charakter ubezpieczenia, podnoszone są argumenty za dopuszczalnością stosowania wyłączeń odpowiedzialności ubezpieczyciela, jak analizowane w niniejszym opracowaniu. Faktem jest, że ubezpieczenia grupowe charakteryzują się przede wszystkim specyficznym sposobem nawiązywania stosunku prawnego i obejmowania ochroną ubezpieczeniową kolejnych ubezpieczonych. Ta specyfika (natura) ubezpieczeń grupowych mogłaby stanowić aksjologiczne uzasadnienie przyjęcia odrębnej regulacji prawnej (w niektórych aspektach odchodzącej od reguł przewidzianych dla umów ubezpieczenia w ogólności], de lege lata jednak ubezpieczenia grupowe musza w pierwszej kolejności sprostać wymaganiom nałożonym generalnie - na wszystkie stosunki ubezpieczenia - przez bezwzględnie obowiązujące przepisy ustawy. Dopiero w kwestiach pozostawionych do rozstrzygnięcia przez ustawodawcę stronom, możliwy będzie argument z natury tego rodzaju zobowiązania dla wyprowadzenia wykładni innej, niż należałoby przyjać w przypadku ubezpieczeń indywidualnych.

75. Zob. wyrok SN z dnia 23 października 2013r., IV CSK 142/13.

76. Ustawa z dnia 5 sierpnia 2015 r. o zmianie ustawy o ochronie konkurencji i konsumentów oraz niektórych innych ustaw (Dz.U. 2015 poz. 1634). 
De lege ferenda regulacja wprost dotycząca ubezpieczeń grupowych powinna w końcu znaleźć swoje miejsce w kodeksie cywilnym. Potrzeba taka wynika zarówno z powszechności tego rodzaju ubezpieczeń na rynku krajowym, rosnącej w obliczu ich powszechnego wykorzystywania w bancassurance, jak i z niepewności w zakresie indywidualnych rozstrzygnięć w razie pojawienia się zagadnień spornych. Ta ostatnia nie służy ani konsumentom, ani ubezpieczycielom. Nie do końca sprostała tym oczekiwaniom propozycja nowelizacji kodeksu cywilnego, przedstawiona przez Komisję Kodyfikacyjną Prawa Cywilnego?? Zastrzeżenia może budzić w kontekście podjętej w niniejszym opracowaniu problematyki regulacja projektowanego art. $805^{1}$ k.c., w świetle której przepisy działu I rozdziału XXVII k.c. należałoby stosować „odpowiednio do umowy ubezpieczenia grupowego na rzecz osób trzecich z uwzględnieniem jej celu i właściwości”. Wạtpliwości budzi fakt, że odesłanie to dotyczy wyłacznie działu I. W projektowanych przepisach art. $834^{1}-834^{12}$ k.c., pojawia się kilkakrotnie explicite odesłanie - w bardzo jednak ograniczonym zakresie - do przepisów działu III. Mogłoby to uzasadniać interpretację, w świetle której w pozostałym zakresie (a contrario) przepisy te nie znajdowałyby zastosowania w przypadku ubezpieczeń grupowych, z uwagi właśnie na ich „cel i właściwości”. To ostatnie sformułowanie z racji swojej wyjątkowej nieprecyzyjności również może przynieść wạtpliwe skutki praktyczne i nawet zwielokrotnić wạtpliwości niż wyeliminować obecny stan niepewności. Trudno też powyższy przepis umiejscowić w kontekście art. 807 k.c. - nie jest zrozumiałe, jak miałoby przebiegać stosowanie tego przepisu „odpowiednio". Przepis ten należałoby stosować z modyfikacjami (jakimi?), bowiem stosowanie go wprost wypaczałoby sens proponowanego uregulowania. W końcu wydaje się, że projektowana regulacja, w szczególności właśnie wobec proponowanej treści nowego art. 805 k.c., nie odpowiada modelowi przyjętemu dotychczas przez ustawodawcę ${ }^{78}$. Dosyć szczegółowe uregulowanie kwestii o charakterze drugorzędnym (w dużej mierze technicznym) wobec odstapienia od przejrzystości zagadnień newralgicznych, jaką stara się dziś gwarantować art. 807 k.c., de facto mogłoby przynieść skutek odwrotny od zamierzonego - ustalić i uporządkować zasady zawierania, przystępowania i wykonywania umów grupowych głównie od strony technicznej, kosztem faktycznej deregulacji zakresu świadczonej ochrony ubezpieczeniowej i zasad odpowiedzialności zakładu ubezpieczeń. ${ }^{29}$

Biorąc pod uwagę kompleksowość rozwiązań przewidzianych w Zasadach Europejskiego Prawa Ubezpieczeń słuszny wydaje się postulat ${ }^{80}$, aby uwzględnić je w toku ewentualnych prac legislacyjnych nad zapowiadanymi zmianami. PEICL powstały w oparciu o kompleksowe badania

77. Projekt ustawy o zmianie ustawy - Kodeks cywilny wraz z uzasadnieniem, Komisja Kodyfikacja Prawa Cywilnego, źródło: https://bip.ms.gov.pl/Data/Files/_public/kkpc/projekty-na-stronie-ms/6-kkpc--grupowki--teskt-i-uzasadnienie-final-28-11-2014-do-dprc.doc [dostęp: 15.12.2017].

78. Mimo, że co innego sugerują motywy wskazane przez samych projektodawców: „Analizowany problem dotyczy niewystarczającej ochrony prawnej osób ubezpieczonych w umowach ubezpieczenia grupowego, który jednak ujawnił się w jednym z segmentów wykorzystywania tej konstrukcji, tj. na rynku bankowo-ubezpieczeniowym" (Uzasadnienie projektu, s. 3).

79. Uwagi krytyczne wobec projektu podnosili również m.in. M. Orlicki, Uwagi do projektu nowelizacji kodeksu cywilnego odnoszqcej się do ubezpieczeń grupowych, Dziennik Ubezpieczeniowy 2015, źródło: http:// dziennikubezpieczeniowy.pl/pub/2015-01-16_opinia__rlickiego.pdf [dostęp: 15.12.2017]; A. Dabrowska, Wstępna koncepcja zmiany przepisów kodeksu cywilnego w zakresie wprowadzenia regulacji dotyczqcych ubezpieczeń grupowych przygotowana przez Komisję Kodyfikacyjnq Prawa Cywilnego - stanowisko Rzecznika Ubezpieczonych, Monitor Ubezpieczeniowy 2015, nr 60, s. 89.

80. M. Fras, 0 dwóch typach umowy ubezpieczenia grupowego, „Prawo asekuracyjne” 2016, Nr 3, s. 31-32. 
prawnoporównawcze ${ }^{81}$, które doprowadziły ich twórców do wniosku o konieczności wyodrębnienia regulacji szczególnej dotyczącej umów ubezpieczenia grupowego. Zaproponowane w jednolitych zasadach rozwiązania czerpia z dorobku legislacyjnego i doktrynalnego ustawodawstw oferujących pewne doświadczenia w tej materii, tym bardziej więc powinny stanowić istotny punkt odniesienia i sferę zainteresowań projektodawców w toku prac nad regulacjami polskimi.

\section{Podsumowanie}

Z aprobatą należy przyjać kształtującą się w orzecznictwie i krystalizującą się w doktrynie ostrożność w przyjmowaniu dopuszczalności szerokiego spektrum wyłączeń lub ograniczeń odpowiedzialności ubezpieczyciela i przeprowadzenie linii delimitującej takie praktyki wobec uzasadnionych oczekiwań uczestników obrotu co do efektywności ochrony ubezpieczeniowej oraz przypisanej wybranemu rodzajowi ubezpieczeń funkcji. ${ }^{82} 0$ ile więc nie jest kwestionowana w ogólności dopuszczalność stosowania w ogólnych warunkach ubezpieczeń postanowień wyłączających lub ograniczających odpowiedzialność ubezpieczyciela, o tyle nie mogą one doprowadzać do sytuacji, w której udzielana ochrona byłaby jedynie iluzoryczna. Odpowiada to wyrażonemu w doktrynie francuskiej warunkowi »ograniczonej« natury wyłączeń odpowiedzialności zakładu ubezpieczeń (kryterium formelle et limiteé), sprowadzającego się do wymogu by ich liczba i zakres nie sprawiały, że umowa ubezpieczenia z punktu widzenia ubezpieczającego pozbawiona byłaby większego znaczenia. ${ }^{83}$

Nabiera to szczególnego znaczenia wobec treści ogólnych warunków umów ubezpieczeń na życie. Prostota i przejrzystość mechanizmów ich funkcjonowania odpowiada uzasadnionym oczekiwaniom uczestników obrotu. Słusznie więc przyjęty został przez ustawodawcę polskiego model imperatywnego zakreślenia istoty zakresu ochrony udzielanej w ramach ubezpieczeń na życie. Tak więc to bezwzględnie obowiązujące przepisy prawa powinny zapewnić elementarną skuteczność ochrony uzasadnionych interesów ubezpieczających (ubezpieczonych), a więc stanowić pierwszorzędne kryterium oceny wyłączeń egzoneracyjnych. Minimalny standard ochrony przewidziany przez ustawodawcę polskiego wydaje się zarazem racjonalny i wystarczający. De lege lata, poszukiwanie przez sądy innych, uzupełniających źródeł i mechanizmów ochrony strony słabszej stosunku prawnego, może następować dopiero wtedy gdy standard ten sam w sobie nie zapewnia jej skutecznie.

Mimo podniesionych zastrzeżeń, z aprobatą należy przyjać także sposób, w jaki rozstrzygnięto w judykaturze (a nawet wyklarowano pewną, stosunkowo jednolitą linię orzeczniczą) zagadnienia

81. Ambicją twórców $P E I C L$ nie jest tworzenie innowacyjnych regulacji, ale wykorzystywanie tradycji doktrynalnych i ustawodawczych państw członkowskich do wypracowywania jednolitych rozwiązań - por. Z. Brodecki, D. Maśniak, Principles of European Insurance Contract Law jako element zintegrowanego porzqdku prawnego, w: Współczesne problemy prawa zobowiqzań, pod red. A. Olejniczaka, J. Haberki, A. Pyrzyñskiej, D. Sokołowskiej, Warszawa 2015, s. 102.

82. M. Serwach, Wykładnia postanowień wyłączajqcych lub ograniczajqcych odpowiedzialność zakładu ubezpieczeń w ubezpieczeniach majqtkowych, w: Odpowiedzialność cywilna. Księga pamiqtkowa ku czci Profesora Adama Szpunara, pod red. M. Pyziak-Szafnickiej, Kraków 2004, s. 423-440.

83. Por. M. Serwach, op. cit., s. 431 i cytowane tam szeroko publikacje doktryny francuskiej, m.in. G. Viney, Traite de Droit Civil. Les obligations La Responsabilite: effets, L. G. D. J., Paris 1988. 
incydentalne - przesłanki kontroli abuzywności postanowień wzorców umów: status prawny ubezpieczonego w ubezpieczeniach na cudzy rachunek (w tym również ubezpieczeniach grupowych) jako konsumenta, relewantność indywidualnych negocjacji postanowień wzorca toczących się między ubezpieczającym a ubezpieczycielem wobec ubezpieczonego, a także - najistotniejsze - przesądzenie o relacji pomiędzy pojęciem warunków określających główne świadczenia stron a postanowieniami wyłączającymi lub ograniczającymi odpowiedzialność ubezpieczyciela. To te ostatnie będą najczęściej przedmiotem kontroli w świetle art. $385^{1}-385^{3}$ k.c. z uwagi na ich doniosłość prawną, najczęściej bowiem pełnia przesądzającą rolę w przedmiocie aktualizacji przesłanek odpowiedzialności ubezpieczyciela. Wnioski zaś co do sprzeczności z dobrymi obyczajami pewnych kategorii wyłączeń odpowiedzialności ubezpieczyciela, posłużyć moga jako punkt odniesienia w sprawach, w których kontrola postanowień wzorca w oparciu o art. $385^{1}$ k.c. będzie prawnie możliwa. Są one bowiem u swych aksjologicznych postaw wyjątkowo trafne i słuszne.

Generalne, nieograniczone wyłączenie odpowiedzialności ubezpieczyciela w ubezpieczeniach na życie za wypadek ubezpieczeniowy będący następstwem przyczyn tkwiących w stanie zdrowia ubezpieczonego przed dniem objęcia go ochroną ubezpieczeniową należy uznać za sprzeczne z art. 834 k.c., a w okresie nieobjętym dyspozycją tego przepisu - zmierzające do obejścia rygorów art. 815 k.c. Stąd też w toku kontroli postanowień przewidujacych tego rodzaju ograniczenia świadczonej ochrony, sąd z urzędu winien odmawiać im mocy wiążącej nie z uwagi na ich potencjalna abuzywność (art. $385^{1}$ k.c.), ale sprzeczność z bezwzględnie obowiązującymi przepisami ustawy (art. 58 k.c.). Nie rodzi to ryzyka upadku całego stosunku ubezpieczenia (art. 58 § 3 in fine k.c.), bowiem trudno będzie przedstawić rozsądne argumenty, nie zmierzające do nadużycia prawa przez ubezpieczyciela (art. 5 k.c.), dla których w braku rzeczonego wyłączenia, strony w ogóle do umowy nie przystapiłyby. Stanowi on przecież formę dyskrecjonalnego ograniczenia obowiązków umownych tylko jednej ze stron, zobowiązanej przez samego ustawodawcę do kwalifikowanej, profesjonalnej staranności (także na etapie przedkontraktowym).

\section{Wykaz źródeł}

\section{Literatura}

Aneks do raportu Rzecznika Ubezpieczonych z 2007 r. pt. „Podstawowe problemy bancassurance w Polsce” - skargi z zakresu bancassurance wniesione w 2012 r., Rzecznik Ubezpieczonych, Warszawa 2012; https://rf.gov.pl/pdf/Aneks_do_raportu_o_bancassurance_2012.pdf [dostęp: 12.12.2017]

Bednarek M., Wzorce umów, w: System Prawa Prywatnego. Prawo zobowiqzań - część ogólna. Tom 5, pod red. E. Łętowskiej, wyd. 2, Warszawa 2013

Brodecki Z., Maśniak D., Principles of European Insurance Contract Law jako element zintegrowanego porzadku prawnego, w: Współczesne problemy prawa zobowiqzań, pod red. A. Olejniczaka, J. Haberki, A. Pyrzyñskiej, D. Sokołowskiej, Warszawa 2015

Dąbrowska A., Wstępna koncepcja zmiany przepisów kodeksu cywilnego w zakresie wprowadzenia regulacji dotyczqcych ubezpieczeń grupowych przygotowana przez Komisję Kodyfikacyjnq Prawa Cywilnego - stanowisko Rzecznika Ubezpieczonych, Monitor Ubezpieczeniowy 2015, nr 60. 
Financial Ombudsman (United Kingdom], Pre-existing medical conditions in short-term insurance policies, http://www.financial-ombudsman.org.uk/publications/technical_notes/medicalconditions.htm [dostęp: 12.12.2017]

Fras F., Umowa ubezpieczenia grupowego. Aspekty prawne, Warszawa 2015

Fras M., 0 dwóch typach umowy ubezpieczenia grupowego, „Prawo asekuracyjne” 2016, Nr 3

Gorzko P., Glosa do uchwały SN z dnia 13 stycznia 2011 r., III CZP 119/10, System Informacji Prawnej LEX, 2012

Gumularz M., Ubezpieczenia na cudzy rachunek - pozycja prawna konsumenta (ubezpieczonego), w: „Radca Prawny”, Warszawa 2013

Handschke J., Kęszycka B., Kowalewski E., Problematyka grupowych ubezpieczeń na życie w świetle znowelizowanych przepisów k.c. o umowie ubezpieczenia. Spór o intencje ustawodawcy, „Wiadomości Ubezpieczeniowe” 2007, nr $7 / 8$

Kodeks cywilny. Komentarz, pod red. K. Osajdy, wyd. 17, Warszawa 2017

Kodeks cywilny. Komentarz. Tom III. Zobowiqzania - część ogólna, pod red. A. Kidyby, wyd. II, SIP LEX, Warszawa 2014

Kodeks cywilny. Tom II. Komentarz. Art. 450-1088, pod red. M. Gutowskiego, wyd. 1, Warszawa 2016 Krajewski M., Umowa ubezpieczenia. Art. 805-834 KC. Komentarz, Warszawa 2016

L. Jacobson, Pregnancy a ,pre-existing condition'? Yes, for some, PolitiFact.com. Retrieved January 17, 2010; http://www.politifact.com/truth-o-meter/article/2009/aug/18/pregnancy-pre-existing -condition/ [dostęp: 12.12.2017].

Łętowska E., Osajda K., Zbieg norm prawa cywilnego, w: System Prawa Prywatnego. Prawo cywilne - część ogólna. Tom I, pod red. M. Safjana, Warszawa 2012

Łętowska E., Zbieg norm w prawie cywilnym, Warszawa 2002

Maśniak D., Specyfika ubezpieczeń grupowych w świetle ustawy o działalności ubezpieczeniowej i reasekuracyjnej i kodeksu cywilnego, w: „Gdańskie Studia Prawnicze”, Gdańsk 2016

Mogilski W., Umowa ubezpieczenia na rzecz osoby trzeciej, w: Ubezpieczenia w gospodarce rynkowej, t. I, pod red. A. Wạsiewicza, Bydgoszcz 1994

Mrozowska-Bartkiewicz B., Tarasiuk-Flordowska A., Grupowa umowa ubezpieczenia na życie a ocena ryzyka ubezpieczeniowego - problemy praktyczne, „Wiadomości Ubezpieczeniowe” 2013, nr 2 Nawracała J., Ograniczenie odpowiedzialności ubezpieczyciela z tytułu ryzyk, które wystapiły przed zawarciem umowy ubezpieczenia (na przykładzie klauzuli wpisanej do rejestru niedozwolonych postanowień pod nr 3456), „Wiadomości Ubezpieczeniowe” 2013, nr 1

Nowakowski Z.K., Wạsiewicz A., Prawo ubezpieczeń majqtkowych i osobowych, Warszawa-Poznań 1973

Orlicki M., Umowa ubezpieczenia, w: System Prawa Prywatnego. Prawo zobowiqzań - część szczegółowa. Tom 8., pod red. J. Panowicz-Lipskiej, wyd. 2, Warszawa 2011

Orlicki M., Uwagi do projektu nowelizacji kodeksu cywilnego odnoszqcej się do ubezpieczeń grupowych, Dziennik Ubezpieczeniowy 2015, źródło: http://dziennikubezpieczeniowy.pl/pub/201501-16_opinia_Orlickiego.pdf [dostęp: 15.12.2017]

Pacuła K., Przepisy wymuszajace swoje zastosowanie jako instrument ochrony „strony słabszej” umowy ubezpieczenia, „Przegląd Prawa Prywatnego Międzynarodowego” 2014

Podstawowe problemy bancassurance w Polsce - raport Rzecznika Ubezpieczonych, Rzecznik Ubezpieczonych, Warszawa 2007; https://rf.gov.pl/files/108_40_Raport_bancassurance.pdf [dostęp: 13.12.2017] 
Popiołek W., art. 385¹ w: Komentarz do kodeksu cywilnego, t. I, pod red. K. Pietrzykowskiego, Warszawa 2015

Prawo ubezpieczeń gospodarczych. Tom II. Komentarz, pod. red. M. Gilcza, M. Serwach, wyd. II, SIP LEX, 2010

Principles of European Insurance Contract Law (PEICL), J. Basedow (red.), Verlag Otto Schmidt, Köln 2016

Serwach M., Wykładnia postanowień wyłaczajacych lub ograniczajqcych odpowiedzialność zakładu ubezpieczeń w ubezpieczeniach majatkowych, w: Odpowiedzialność cywilna. Księga pamiqutkowa ku czci Profesora Adama Szpunara, pod red. M. Pyziak-Szafnickiej, Kraków 2004 Sieradzka M., Glosa do uchwały SN z dnia 13 stycznia 2011 r., III CZP 119/10, System Informacji Prawnej LEX, 2011

Stroiński E., Ubezpieczenia na życie: teoria i praktyka, Warszawa 2003

Szanciło T., Glosa do uchwały SN z dnia 13 stycznia 2011 r., III CZP 119/10, „Glosa” 2012, Nr 2

Szczepańska M., Funkcje ubezpieczeń na życie, w: Ubezpieczenia na życie. Aspekty prawne, Warszawa 2008

Szymański Z., Ubezpieczenia następstw nieszczęśliwych wypadków, Warszawa 1980

W. Kamieński, Wyłaczenie odpowiedzialności ubezpieczyciela z uwagi na przyczyny wypadku dotyczqce okresu przed rozpoczęciem ochrony ubezpieczeniowej, „Rozprawy Ubezpieczeniowe”, $\mathrm{nr} 19$ (2/2015)

Zoll F., Prawo bankowe. Komentarz, t. II, Komentarz do art. 92A-194, Kraków 2005

Zasady Dobrej Praktyki Bankowej - Kodeks Etyki Bankowej z dnia 18 kwietnia 2013 r., Związek Banków Polskich, Warszawa 2013; źródło: https://zbp.pl/public/repozytorium/dla_konsumentow/rekomendacje/KEB_final_WZ.pdf [dostęp: 14.01.2018].

Zasady Dobrych Praktyk Polskiej Izby Ubezpieczeń z dnia 8 czerwca 2009 roku, Polska Izba Ubezpieczeń, Warszawa 2009; źródło: https://piu.org.pl/zasady-dobrych-praktyk/ [dostęp: 14.01.2018].

\section{Akty prawne}

ustawa z dnia 11 września 2015 r. o działalności ubezpieczeniowej i reasekuracyjnej (t.j. Dz.U. z 2017 r. poz. 1170 z późn. zm.)

ustawa z dnia 5 sierpnia 2015 r. o zmianie ustawy o ochronie konkurencji i konsumentów oraz niektórych innych ustaw (Dz.U. 2015 poz. 1634).

ustawa z dnia 23 sierpnia 2007 r. o przeciwdziałaniu nieuczciwym praktykom rynkowym (t.j. Dz.U. z 2017 r. poz. 2070)

ustawa z dnia 22 maja 2003 r. o działalności ubezpieczeniowej. (t.j. Dz. U. z 2015 r. poz. 1206 z późn. zm.)

dyrektywa Rady 93/13/EWG z dnia 5 kwietnia 1993 r. w sprawie nieuczciwych warunków w umowach konsumenckich (Dz. U. UE. L. z 1993 r. Nr 95, str. 29 z późn. zm.) 


\section{Akty nienormatywne}

Zasady Europejskiego Kontraktowego Prawa Ubezpieczeniowego, ang. Principles of European Insurance Contract Law - w tłumaczeniu na język polski D. Fuchsa, Ł. Szymańskiego i M. Boguskiej http://www.restatement.info/ [dostęp: 15.12.2017] [zakładka: PEICL in full text)

Uzasadnienie projektu ustawy o działalności ubezpieczeniowej i reasekuracyjnej, druk sejmowy nr 3644, http://orka.sejm.gov.pl/Druki?ka.nsf/0/C8757DC68795390DC1257E?D004981FE/\% 24File/3644-uzasadnienie.docx [dostęp: 15.12.2017]

Projekt ustawy o zmianie ustawy - Kodeks cywilny wraz z uzasadnieniem, Komisja Kodyfikacja Prawa Cywilnego, źródło: https://bip.ms.gov.pl/Data/Files/_public/kkpc/projekty-na-stronie-ms/ 6-kkpc--grupowki---teskt-i-uzasadnienie-final-28-11-2014-do-dprc.doc [dostęp: 15.12.2017] Rekomendacja S dotyczqca dobrych praktyk w zakresie zarzadzania ekspozycjami kredytowymi zabezpieczonymi hipotecznie, Komisja Nadzoru Finansowego, Warszawa 2013, źródło: https://www.knf.gov.pl/knf/pl/komponenty/img/Rekomendacja_S_18-01-2011_25296_225296. $\operatorname{pdf}[14.01 .2018]$

\section{Orzecznictwo}

wyrok Trybunału Sprawiedliwości UE z dnia 9 lipca 2015 r. w sprawie C-348/14, Maria Bucura przeciwko SC Bancpost SA, EU:C:2015:44?

wyrok Trybunału Sprawiedliwości UE z dnia 1 października 2015 r. w sprawie C-32/14, ERSTE Bank Hungary Zrt. v. Attila Sugár, ZOTSiS 2015/10/I-63?

wyrok Trybunału Sprawiedliwości UE z dnia 23 kwietnia 2015 r. w sprawie C-96/14, Jean-Claude Van Hove v. CNP Assurances SA

wyrok Trybunału Sprawiedliwości UE z dnia 30 kwietnia 2014 r., Árpád Kásler i Hajnalka Káslerné Rábai v. OTP Jelzálogbank Zrt, C-26/13, Z0TSiS 2014/4/I-282

wyrok Trybunału Sprawiedliwości UE z dnia 14 czerwca 2012 r., Banco Espanol de Crédito SA, C 618/10, ZOTSiS 2012/6/I-349

wyrok Trybunału Sprawiedliwości UE z dnia 27 czerwca 2000 r., w połączonych sprawach C - 240/98 oraz C-244/98, Océano Grupo Editorial and Salvat Editores, ECR 2000/6/I-4941

wyrok Trybunału Sprawiedliwości UE z dnia 06 lipca 1995 r. w sprawie C-470/93, Verein gegen Unwesen in Handel und Gewerbe Köln e.V. v. Mars GmbH, ECR 1995, s. I-01923

uchwała Sadu Najwyższego z dnia 13 stycznia 2011 r., III CZP 119/10, OSNC 2011/9/95 wyrok Sądu Najwyższego z dnia z 14 lipca 2017 r.; II CSK 803/16 wyrok Sądu Najwyższego z dnia 16 kwietnia 2015 r., III SK 42/14 wyrok Sąu Najwyższego z dnia 12 marca 2015 r., I CSK 165/14 wyrok Sądu Najwyższego z dnia 23 października 2013r., IV CSK 142/13 wyrok Sądu Najwyższego z dnia 12 września 2013 r. IV CSK 91/13 wyrok Sądu Najwyższego z dnia 20 stycznia 2011 r., I CSK 218/10 wyrok Sądu Najwyższego z dnia 08 czerwca 2004r., I CK 635/03 
wyrok Sądu Apelacyjnego w Warszawie z dnia 08 stycznia 2015 r., I ACa 762/14

wyrok Sądu Apelacyjnego w Warszawie z dnia 19 czerwca 2013 r., VI ACa 1494/12 wyrok Saqdu Apelacyjnego w Warszawie z dnia 19 czerwca 2013 r., VI ACa 1494/12 wyrok Sądu Apelacyjnego w Warszawie z dnia 12 czerwca 2012 r., XVII AmC 1039/09 wyrok Sadu Apelacyjnego w Warszawie z dnia 29 grudnia 2011 r., VI Ca 855/11 wyrok Sadu Apelacyjnego w Warszawie z dnia 17 listopada 2011r., ACa 1472/11

wyrok Sądu Okręgowego w Łodzi z dnia 22 lutego 2016 r., III Ca 1651/15 wyrok Sądu Okręgowego w Koszalinie z dnia 27 października 2015 r., I C 152/12 wyrok Sądu Okręgowego w Częstochowie z dnia 17 maja 2012 r., I C 281/11

\section{Insurer's liability exclusion in a group life insurance for a death caused by a pre - existing condition}

\section{Summary}

Group life insurance in Poland, particularly popular on the bancassurance market and workers 'programme, very often includes pre-existing medical condictions provision. This means that the insurer does not evaluate the risk based on medical interview (questionnaire), but excludes its liability for an insurance accident caused by an illness existing in the insured party before joining the insurance. The popularity of this type of insurance was not reduced by the fact that pre-existing mediacial conditions provisions were considered abusive by the SOKiK (the court of competition and consumer protection]. This article is devoted to the admissibility of including such provisions in general terms of insurance in the light of Polish law and correctness of their legal qualification performed by Polish courts. The problem of relations between arguments involving the nature and specificity of group insurance and the legal regulation regarding the scope of insurance cover in life insurance will also be discussed.

MGR DAWID ROGOZIŃSKI-absolwent Wydziału Prawa i Administracji Uniwersytetu Gdańskiego. 